\title{
REVIEW
}

\section{Viral vaccine stabilizers: status and trends}

\author{
F. M. C. CARDOSO ${ }^{1}$, D. PETROVAJOVÁ ${ }^{1}$, T. HORŇÁKOVÁ 1,2
}

\begin{abstract}
${ }^{1}$ Research and Development Department, Imuna Pharm a.s., Jarková 17, 08222 Šarišské Michalany, Slovak Republic; ${ }^{2}$ Olomouc University Social Health Institute (OUSHI), Olomouc, Czech Republic
\end{abstract}

Received November 11, 2016; accepted January 4, 2017

\begin{abstract}
Summary. - Vaccine stability is a key factor to preserve vaccine potency and efficiency, as its potency decays over time and during temperature changes. The choice of stabilizers for viral vaccine formulation depends mainly on the vaccine type. More specifically, the choice is determined by the properties and structure of the active pharmaceutical ingredient or viral antigen(s) in the vaccine. In this review, we analyze key formulation components in different vaccine types. We discuss some of the major driving forces in the improvement of vaccine thermostability: increasing demand for cost-effective production of thermostable vaccine with lower dependency on cold chain, stricter regulatory policies for animal-origin materials, and the return of the research investment from the industry point of view. Moreover, we provide an overview of existing licensed viral vaccine types, including their production platform, presentation, delivery route, known stabilizers content and available thermostability data. In addition, we compare the data of licensed vaccines to published experimental vaccines, in order to discuss the current trends in vaccine stabilizers development.
\end{abstract}

Keywords: vaccines; viruses; stabilizers; thermostability; protein components; formulation

\section{Contents:}

1. Introduction

2. Viral vaccine types and their stability

3. Vaccine excipients and safety regulations

4. Cold chain and thermostable vaccine innovation in industry

5. Stabilizers in licensed and experimental vaccines

6. Conclusions

\section{Introduction}

It is widely accepted that vaccination has been one of the most successful medicine tools. By the first half of the $20^{\text {th }}$

E-mail: miguel.lopez.cardoso@gmail.com; phone: +56-945012852. Abbreviations: API = active pharmaceutical ingredient; GRAS = generally regarded as safe; HSA = human serum albumin; IN = inactivated vaccines; $\mathrm{LAV}=$ live-attenuated vaccines; $\mathrm{SUB}=$ subunit or recombinant vaccines; VLP = virus-like particles century, newly developed cell culture techniques allowed in vitro pathogen passaging, resulting in the attenuation of several medically relevant infectious diseases agents. Throughout the last 200 years, several technology waves have helped to define the most important milestones in vaccine history, considering five past revolutions in vaccinology: virus attenuation, virus inactivation, cell culturing of viruses, genetic engineering and induction of cell-mediated immunity by vaccine (Plotkin, 2005). In the $21^{\text {st }}$ century, genetically engineered vaccines, reverse vaccinology and potent immunoselective adjuvants are the main vaccine innovative driving forces. It is expected that one or several of these innovations would become a market game-changer and will contribute to the next vaccine revolution. The development of these innovative technologies can be considered as a reaction to: progressively stricter safety concerns of regulatory agencies; need for more potent and cost-effective vaccines and increase the effectiveness of the vaccine immunization coverage.

The viral antigen(s) or active pharmaceutical ingredient (API) is the immunogenic component of the vaccine. Until 
recently, the API structural analysis prior to stabilizers formulation selection has not been used in the process of the vaccine formulation. Historically, vaccine formulations have been relying heavily on empirical approaches, resulting mostly in successful vaccines, but with limited thermostability. Nowadays, an important part of the vaccination coverage effectiveness relies on the maintenance of an expensive cold chain systems used to ensure proper vaccine storage, distribution and administration. However, the constant streaming of new scientific information regarding virus structure, infection and immune system regulation is making the selection of stabilizers in vaccine development more scientifically-driven. In line with this tendency, new technological advancements based in time-saving high-throughput technologies (Schlehuber et al., 2011; Walter et al., 2012) and rational and systematic antigen structure-based vaccine formulation (Morefield, 2011) represent major current trends in vaccine development. In this review, we discuss recent scientific, regulatory and economical constrains and their impact on current viral vaccines stabilizers development. We further focus on the correlation of the API characteristics with components of the licensed vaccines, to compare them with components of publically available experimental vaccine data and to analyze current trends in vaccine stabilizers development.

\section{Viral vaccine types and their stability}

Based on current vaccine stabilizers data, the more complex is the API the more complex tends to be its vaccine formulation. Notably, viral vaccines with their complex structure and functioning, expensive production and high safety risks represent a particular challenge to the pharma industry and regulatory agencies worldwide. There are three different viral vaccine types: the live attenuated vaccines (LAV), the inactivated vaccines (IN), and the recombinant or subunit vaccines (SUB). As their API structural characteristics are remarkably different, API complexity correlates with the vaccine variable stability.

The LAV were among the first vaccines ever used in humans (e.g. smallpox, rabies, tuberculosis, yellow fever; Plotkin, 2014), and in the first half of the $20^{\text {th }}$ century vaccine attenuation resulted in a significant decrease in pathogenicity. During the second half of the $20^{\text {th }}$ century, several relevant viral LAV had a breakthrough success, including: polio, measles, mumps, rubella, adenovirus, varicella, rotavirus and influenza virus vaccines (Plotkin, 2014). In most cases, viral LAV replication within the host is as potent as the wild type virus, without the onset of disease symptoms. LAV potency correlates directly with their replicative potential, resulting in a sustained immune response, including innate response (inflammation), but most importantly a strong adaptive response (antigen-specific antibody production and a strong cellular-mediated response). The LAV has been historically known for their efficacy, but structural changes induced by external factors impact their potency, with the temperature as the most critical. Depending on the structure of viral capsid outer layer, the LAV virus capsid can be either enveloped (i.e. containing a host lipid membrane: measles, mumps, influenza, smallpox, rabies viruses) or capsid protein (i.e. geometric arrangement of copies of one or more viral proteins: polio virus, adenovirus, rotavirus, papilloma virus). Independently of their API complexity and structural architecture of their capsid, most LAV are thermosensitive and require rich formulations to create a complex glassy matrix to prevent lipid membrane hydration and protein aggregation (Alcock et al., 2010). Based on available information, LAV formulations consist of buffers (e.g. phosphate, citrate) including one or two of the following stabilizers types: i) protein components (e.g. peptides, amino acids, human serum albumin, lactoalbumin, gelatin, polygeline) or ii) sugar and sugar alcohols (e.g. sucrose, trehalose, sorbitol, mannitol, lactose) (Table 1). Therefore, licensed LAV formulation is mostly limited to solid state (lyophilization), with a few exceptions. Since LAV immunogenicity relies on replicative component, the major goal of LAV technological development is the optimization of its stabilizers composition.

The IN are live vaccines inactivated by virion exposition to a cross-linking agent that does not affect their antigenicity. Among the most commonly used commercial vaccines inactivating agents are the formaldehyde (as formalin) and $\beta$-propiolactone (Perrin and Morgeaux, 1995). Due to their inactivation, IN vaccines do not have a replicative potential (a desirable vaccine safety feature for regulatory authorities), and the immunological response triggered is less potent in comparison to LAV. Consequently, in most of the inactivated IN vaccines, effectiveness relies on the wide use of adjuvants in their formulation, and/or subsequent boosting dose(s). Since IN vaccines require an adjuvant, it is of the outmost importance to preserve the desired physicochemical properties of the API-adjuvant complex, in order to elicit the desired immune response. Nowadays, the selection of the

Table 1. Different classes of "generally regarded as safe" (GRAS) excipients and examples found in licensed viral vaccines

\begin{tabular}{ll}
\hline Excipient class & Examples \\
\hline Amino acids & $\begin{array}{l}\text { arginine, aspartate, glycine, glutamate, histi- } \\
\text { dine, lysine, proline } \\
\text { ascorbic acid, EDTA, malic acid } \\
\text { Antioxidants }\end{array}$ \\
Proteins & $\begin{array}{l}\text { dextrose, glycerol, lactose, mannitol, myo- } \\
\text { inositol, sorbitol, sucrose, trehalose }\end{array}$ \\
Sugars/polyols & pluronic, tween, polysorbate \\
Surfactants &
\end{tabular}


Table 2. Licensed adjuvants used in human inactivated (IN) vaccines

\begin{tabular}{|c|c|c|c|}
\hline Adjuvant & $\begin{array}{l}\text { Representative } \\
\text { (year when licensed) }\end{array}$ & Components & Vaccines (disease) \\
\hline Mineral salts & Aluminium salts (1924) & $\begin{array}{l}\text { Aluminium phosphate or } \\
\text { hydroxide }\end{array}$ & $\begin{array}{l}\text { Anflu (pandeminc influenza), Ixiaro (Japanase en- } \\
\text { cephalitis), Havrix (rabies), Engerix (hepatitis B), } \\
\text { Gardasil (human papilloma) }\end{array}$ \\
\hline Oil-in-water emulsion & $\begin{array}{l}\text { MF59 (Novartis; 1997), ASO3 } \\
\text { (GlaxoSmithKline; 2009) }\end{array}$ & $\begin{array}{l}\text { Squalene-based emulsions particles, } \\
\text { stabilized with detergents (polysorb- } \\
\text { ate } 80 \text { (Tween } 80 \text {, Span } 85 \text { ) }\end{array}$ & $\begin{array}{l}\text { Fluad (seasonal influenza), Aflunov/Prepandrix } \\
\text { (pre-pandemic influenza), Focetria/Pandremix } \\
\text { (pandemic influenza) }\end{array}$ \\
\hline Liposomes & Virosomes (Berna Biotech; 2000) & $\begin{array}{l}\text { Lipids, viral proteins } \\
\text { (e.g. hemagglutinin) }\end{array}$ & $\begin{array}{l}\text { Inflexal (seasonal influenza) } \\
\text { Epaxal (hepatitis A) }\end{array}$ \\
\hline $\begin{array}{l}\text { Alum-absorbed TLR } 4 \\
\text { agonist }\end{array}$ & AS04* (GlaxoSmithKline; 2005) & Aluminium hydroxide, MPL & $\begin{array}{l}\text { Fendrix (hepatitis B) } \\
\text { Cervarix (human papilloma virus) }\end{array}$ \\
\hline Oil-in-water emulsion & $\begin{array}{l}\text { AF03 (Sanofi Pasteur; 2010, } \\
\text { withdraw in 2011) }\end{array}$ & $\begin{array}{l}\text { Squalene, Montane 80, Eumulgin } \\
\text { B1 PH }\end{array}$ & Humenza (pandemic influenza) \\
\hline
\end{tabular}

licensed adjuvants is surprisingly limited. Aluminium salts (aluminium phosphate or hydroxide) are by far the most widely used adjuvants for more than 70 years (Clapp et al., 2011). However, the unmet need for more selective and potent adjuvants is fueling an intensive research of vaccine adjuvants and is expected to lead to new generation of inactivated vaccines (Garcia and De Sanctis, 2014, Mohan et al., 2013). A brief overview of current licensed adjuvants is given in Table 2, but new promising alternatives to licensed adjuvants are also reported, including the two main groups, TLR antagonists (Fujita et al., 2013) and colloidal carriers (Beg et al., 2013). Because of higher stability of IN vaccines compared with LAV, licensed IN vaccines are available also in liquid form (Supplementary Table S3). When IN vaccines have non aluminium-based adjuvants, the delivery route can be more versatile. For example, the oil-in water preparations (emulsions) and virosomes-based approaches are presented in both, lyophilized and liquid licensed vaccine formulations (Supplementary Table S3).

The genetic engineering is widely used for SUB vaccine production and those vaccines are considered the safest and most promising of the current vaccine types. Viral recombinant or SUB vaccines consist of immunogenic viral proteins and/or polysaccharides, generally from the exterior of the virus capsid. As highly purified proteins tend to be thermostable, by reducing the amount of stabilizers within the formulation, the SUB vaccine is an attractive alternative to IN or LAV vaccines. For example, the SUB vaccine FluBlok ${ }^{\oplus}$ has no additives (Supplementary Table S3). SUB vaccines improved thermostability allows for a variety of innovative delivery routes. On the negative side, SUB vaccines require several boosts for complete protection, which poses an extra vaccine distribution, storage and logistical challenges. Interestingly, there are two relatively recent innovations in SUB vaccines that can target these disadvantages, representing current research trends in SUB vaccine field.
The first innovation is the capacity of some viral proteins to self-assembly into virus like particles (VLP) with more potent immunogenic potential than the single soluble protein. This is achieved by the multi-epitopic nature of VLP, increasing the pathogen recognition by the immune response and inducing strong humoral and cellular responses. One of the main advantages of VLPs is the relatively easy microbial production platform and the possibility of cell-free systems (Rodriguez-Limas, 2013). Notably, licensed vaccines against the human papilloma virus and associated cancer confirm the VLP as an effective platform (Gardasil ${ }^{\circledR}$ and Cervarix ${ }^{\circledR}$ ) (Supplementary Table S3). The second innovation is the reverse engineering, a technique that implies the sequencing of the virus, synthesizing several of its antigens, inducing immune response in vivo, and subsequently developing the most immunogenic antigens as vaccine (Rappuoli, 2000).

\section{Vaccine excipients and safety regulations}

Vaccine excipients comprise all chemical compounds used in the production of vaccines, including: the suspending fluid (e.g. sterile water, saline buffer or fluids containing protein), preservatives (e.g. antibiotics, thiomersal), stabilizers and adjuvants that contribute to the vaccine's efficiency, as well as traces of the culture material (e.g. media, FBS). Vaccine composition varies from one product to another, and different vaccines with the same API can have substantially different formulation composition attributed to production processes. All these aspects represent critical manufacturer know-how and the vaccine stabilizer composition can be protected as intellectual property. Depending on the vaccine type, the inclusion of stabilizing agents can be crucial for API stability. Generally, most of the stabilizers found in commercial viral vaccines are considered as generally regarded as safe (GRAS) compounds (Table 1). The main advantage of using GRAS 
as vaccine stabilizers is the traceability of materials and time saving during the vaccine qualification and certification, by national and international regulatory authorities. One of the biggest challenges for vaccine manufacturers is the constant trend to gradually replace or at least decrease the amount of antibiotics, preservatives and material of animal-origin in vaccines, due to existing and potential safety concerns from contamination by adventitious agents or allergic reactions. For example, antibiotics have an increasing disuse in vaccines, mainly due to allergenic properties of some antibiotics in sensitive persons (anaphylaxis or local skin reactions). However, compared with others (e.g., cephalosporins or sulfa drugs), the most commonly found antibiotics in vaccines are not known to cause severe allergic reactions (e.g. neomycin or polymyxin B), (Georgitis and Fasano, 2001). In addition, the antibiotic trace amount within vaccines is considered not significant, like the neomycin content in vaccines which is normally below $50 \mu \mathrm{g}$ or lower, posing antibiotic content a very unlikely threat to elicit an allergenic response. Another preservative, the thiomersal (an organomercury compound) has been extensively used as a vaccine preservative for more than 80 years, but it is probably one of the most polemic vaccine excipient (Dorea et al., 2013). In 1999 in the USA, the thiomersal started to be substituted as vaccine preservative, and by 2003 no thiomersal vaccine was available in the USA (Food and Drugs Administration, 2013). The removal of thiomersal-containing vaccines in high income countries has recently fueled a continuous debate about discontinuation of thiomersal use in vaccines for human use altogether, questioning the benefits of the thiomersal ban in low and middle-income countries (King et al., 2013).

The preservatives are not the only vaccine components that have been subjected to controversy. Historically, the use of biological material of animal-origin (including humanorigin) has been widely present in vaccine production and formulation, but these components are under constant safety surveillance due to the potential contamination by adventitious agents. The fetal bovine serum (FBS) is one example of animal-origin material used for decades for the cell culture-based vaccine production as a growth additive. The FBS is the most widely used growth additive, but other animals are also used for serum production. Over decades, progressive layers of regulatory restrictions and quality control tests along the vaccine production process have been put in place to minimize the possible contamination of vaccines by adventitious agents. Moreover, serum production is strictly regulated internationally by the European Medicines Agency and the Food and Drug Administration (FDA), and only good manufacturing practices (GMP) grade-certified products tested to be negative for a panel of adventitious agents, can only be used for vaccine development and manufacturing. One of the main animal-origin material risks is the bovine spongiform encephalopathy
(BSE) in bovine-origin products (Baker and Ridley, 1996), including FBS (European Agency for the Evaluation of Medicinal Products, 2009). So far, there are no reported cases of BSE in humans transmitted via vaccines, remaining thus just as theoretical risk.

Even though gelatin is considered as generally regarded as safe (GRAS) excipient, its animal-origin still rises concerns about its safety due to presence of adventitious agents or allergenic properties (Rottem and Shoenfield, 2004), but only extremely rare incidence of anaphylaxis (one per 2 million cases) or urticaria has been reported when gelatin was used as stabilizer (Offit and Jew, 2003). Gelatin is a key component for the lyophilization process of most LAV, so gelatin removal from LAV formulations will be difficult until a suitable viable substitute will be available, being the recombinant human gelatin a promising candidate (Liska et al., 2007). Another commonly used animal-origin vaccine stabilizer is the human serum albumin (HSA), that have been used widely in LAV and combinatory vaccines (Supplementary Table S3), and reported to be linked with enhanced stability of flavivirus vaccine (Wiggan et al., 2011). As an animal-origin product, HSA raises the same concerns as serum or gelatin, and even when HSA has never been linked with any disease transmission in vaccines, again the theoretical risk exists. The FDA requests that vaccines containing HSA have a package label concerning the risk of viral disease transmission or vCJD included. Therefore, there is an increasing trend to substitute the HSA by recombinant albumin of alternative non-animal sources or by mixture of amino acids. For example, the Recombumin ${ }^{\circledR}$ from Albumedix is the first recombinant albumin approved for drug and vaccine manufacturing (Albumedix, 2016). Such increased availability of GMP manufactured non-animal origin amino acids, sugars or recombinant proteins as alternatives for replacement of "classical" animal-origin materials (HSA or gelatin), is one of the most promising strategies for the maximal decrease of adventitious agent's contamination for vaccine production.

Besides the excipients safety concerns, there is also safety concern about the final propagation or production substrate for viral vaccines, were there is a clear tendency to select cell substrates widely regarded as safe. The current selection of substrates varies according to the vaccine type, corresponding also to the vaccine API complexity. For example, for LAV manufacture the primary human cells (WI-38, MRC-5) are mainly chosen, but recently the transformed Vero cell line has been progressively used also, while for IN vaccines the specific pathogen free chicken eggs (SPFCE) represent still the most used substrate. The SUB vaccines are the most substrate innovative vaccine type, where yeast and bacteria are also used with success (Supplementary Table S3). The innovation in vaccine substrates faces the reluctance from vaccine developers, due to complicated, long and costly new 
regulations and recommendation for the acceptance of new vaccine substrate (World Health Organization, 2013).

\section{Cold chain and thermostable vaccine innovation in industry}

The vaccine thermostability is the maintenance of a determined minimal viral potency in a specific thermal range during its shelf-life, and it depends on the vaccine type, API and route of delivery (Kumru et al., 2014). Several private, governmental and academic entities have recognized the current challenge that thermostability poses in the vaccination programs throughout the world. As a major call for this urgent problem, "vaccines that do not require refrigeration" is currently one of the 16 grand challenges in global health put forth by the Bill and Melinda Gates Foundation originally in 2003 (Global Grand Challenges, 2016). The maintenance of appropriate low temperatures for storage and transport of vaccines is paramount in the vaccine distribution network and is called cold chain. Historically, the cold chain maintenance has been focused on avoiding elevated temperatures as source of vaccine instability. Potency loss can be attributed to storage, distribution, vaccine preparation and to administration time gaps. But nowadays, it is the inadvertent exposure to low temperatures of several freeze-sensitive vaccines that represent a serious threat to the thermostability of IN vaccines, especially with IN vaccines containing aluminum adjuvant, where freeze-stable formulations are under development (Braun et al., 2009a). For example, it is revealing that the $75 \%-100 \%$ of IN vaccine shipments have been exposed to freezing temperatures at least once (Matthias et al., 2007), emphasizing the importance of this problem. Failures in the cold chain have been contributed to local outbreaks and disease resurgence in the developing world. For example, during vaccine distribution monitoring in Papua New Guinea, it was found that $100 \%$ of the vaccines were exposed to freezing temperatures, but rarely exposed to elevated temperatures (Wirkas et al., 2007). Theoretically, the maintenance of cold chain is possible in every country, but there are several reasons that hamper its implementation, particularly in low income countries, such as: outdated or improper refrigeration equipment; interruptions of energy supply due not reliable source or infrastructure; poor compliance with cold chain procedures; inadequate monitoring; poor understanding and/or training (Kristensen et al., 2011). Among the most important advantages of vaccines with improved thermostability to high and freezing temperatures, are health and economic aspects such as: the expansion of immunization coverage; minimizing the cost increase, and patient's access to fully potent vaccines; reduced vaccine wastage and turnover by increasing vaccine shelf life (Chen and Kristensen, 2009). On one hand, despite these evident benefits and urgent need for improved thermostability of vaccines, economic constrains, and investment recovery are still the major obstacles for thermostable vaccine development by vaccine manufacturers. Logically, new vaccine stability formulations with innovative improvements must occur within the early phases of vaccine development, but these innovations can impact the costs of vaccine reformulation, extra clinical trials and additional regulatory approvals. On the other hand, an optimization of the vaccine thermostability represents several advantages for vaccine manufacturer as well: higher bulk production efficiency, reducing costs in lowering recalls, temperature controlled storage and transportation. Unfortunately, despite the technological prowess of the thermostable vaccine improvements, the presence of thermostable vaccines in the market or at late clinical phases aimed to licensing is limited (Supplementary Table S3, S4). Therefore, for the pharmaceutical industry it is important to ensure investment recovery, to make thermostable vaccine development attractive. Notably, the customer acceptance and support from governmental regulatory authorities and policymakers, via incentives and guidelines, can make new thermostable vaccine formulations development more attractive to industry. On the other hand, manufacturer should provide an improved product with net potential market advantages over the existing ones with sufficient proves about safety and efficacy of new thermostable vaccines.

\section{Stabilizers in licensed and experimental vaccines}

As mentioned before, composition of viral vaccine formulation is highly variable depending on the vaccine type. Moreover, the information about licensed vaccine components is not always complete, and formulations with same API can be substantially different from one product to another. Using information from summary of product characteristics or package inserts, we collected data from about 71 licensed vaccines types (LAV, IN and SUB vaccines) and their formulations (Supplementary Table S3). Formulation data for 9 out of 71 vaccines were not available. We reason that the number of times a specific stabilizer is mentioned in different vaccine formulations provides approximate information about its spectrum of use. As expected, the collected data showed that stabilizers in current LAV formulations are mostly enriched by well-known GRAS protein excipients such as HSA and/or gelatin with 1+ amino acids, and 1+ sugar components (Supplementary Table S3). Most likely, these rich formulations are required due the high level of complexity and intrinsic instability of API in LAV and IN vaccines, requiring lyophilized formulation, were gelatin 
plays a decisive stabilization role. For example, albumin and gelatin are present in $12 \%$ and $19 \%$ of LAV and IN vaccines, respectively, while in SUB formulations both stabilizers are absent (Supplementary Table S3).

Comparing the licensed vaccine with the experimental vaccine list consisting of 38 vaccines (Supplementary Table S4), the presence of albumin and gelatin in experimental vaccines is reduced by $50 \%$. Within the available data about experimental vaccines, the albumin and gelatin are mentioned in $8 \%$ and $16 \%$, respectively, only in LAV formulations (Supplementary Table S4). Interestingly, amino acids are used in both licensed and experimental vaccines with similar frequency, about $25-30 \%$ of all vaccine type's formulations containing at least one amino acid. Glutamate, arginine, histidine and alanine are the most commonly mentioned amino acids in both licensed and experimental vaccine formulations (Supplementary Table S3 and S4). Most of the formulations that include amino acids are LAV, while in IN and SUB formulations the amino acid presence is reduced or they are not present at all. Amino acid mixtures are used for increasing protein solubility and stability (Golovanov et al., 2004). There are several reasons for amino acid presence in the vaccine formulations, depending on the amino acid physicochemical characteristics. For example, the histidine has antioxidant and buffering properties, by scavenging $\mathrm{HO}^{-}$radicals in solutions (Wade and Tucker 1998) and by controlling $\mathrm{pH}$ and stabilizing non-covalent interaction of solid state proteins (Chen et al., 2003; Tian et al., 2007). Another interesting amino acid is arginine, which is widely known for preventing protein aggregation by interacting with aromatic and charged protein residues (Shukla and Trout, 2010).

Another important stabilizer group within vaccine formulation are sugars (mono /di/polysaccharides). In fact, approximately one third of therapeutic proteins in the pharmaceutical industry are stabilized in sugar glasses, which emphasize their wide use as well as proven stabilizing and protective potential. The sucrose and sorbitol are the most commonly mentioned sugar stabilizers in our licensed vaccine list being present in $20 \%$ and $14 \%$, respectively (Supplementary Table S3.). Interestingly, in the list of experimental vaccines the trehalose is the most commonly found stabilizer among sugars (32\% of experimental vaccine formulations contained trehalose), while sucrose, mannitol and the polysaccharide inulin are used in experimental vaccines with similar frequency (10\%-13\% of formulations). There are several reports supporting the trehalose stabilizing and cryoprotectant properties (Cicerone and Douglas, 2012, Kaushik and Bhat, 2003), suggesting trehalose as the most promising candidate in future LAV vaccine formulations. Moreover, trehalose increasing inclusion in several experimental formulations (i.e. alternative delivery routes: microneedles, spray freeze-dried, liquid and spray dried powder) highlights its versatility and potential of its stabilizing properties. Besides trehalose, the inulin has been also reported as a promising cryo- and lyo- protectant, especially for virosomes (de Jonge et al., 2007).

\section{Conclusions}

Nowadays, the production of cheap, efficient and stable viral vaccines comprises of several strategic, technical and economical challenges to the pharmaceutical industry and health agencies worldwide. In addition, the presence of new or emerging infectious viral diseases, like the pandemic zoonotic influenza H1N1 appearance in 2009 (Fineberg, 2014), the Ebola virus emergency in Central Africa in 2014 (Elshabrawy et al., 2015), or the recent Zika virus outbreaks in Latin America (Jamil et al., 2016), together with the increasing chronic market competitivity, represent a continuous pressure for time and cost-efficient vaccine formulation and production. The development and market innovation of cost-effective thermostable vaccines can alleviate the vaccine demand, potentially being a game changer in low-resources settings for immunization coverage. Current development in vaccine formulation focuses on the importance of structural characterization of the vaccine API, and the need of a systematic formulation analysis to avoid strategic failure resulting in sub-optimal formulation (Morefield, 2011). Inadequate vaccine formulation can result in jeopardizing the safety, efficacy and/or stability of the vaccine, increasing subsequent costs related to recalls, distribution, storage or drop in sales. Current rational approach for vaccine formulation development should thus consist of: API biophysical characterization; adjuvants and stabilizers evaluation; interaction between API and other excipients; production quality control assessment; and chronologic monitoring of stability in real time and in accelerated conditions. The vaccine stabilizer selection shows a clear tendency for substitution of animal-origin material (FBS, gelatin, HSA) for recombinant material, and the progressive inclusion of a sugar component into experimental vaccines (e.g. trehalose or inulin) (Supplementary Table S4). When sugars are included in the formulation, upon dehydration, the proteins are embedded in a sugar glass matrix. Even in the sugar-glasses, protein degradation can occur by chemical (oxidation, hydrolysis, deamination) or physical (aggregation) changes. Unfortunately, the exact mechanism or factors that regulate this degradation process is not completely understood. But several hypotheses have been described in attempts to understand, characterize and quantify the protein degradation rates in sugar glass matrixes (i.e. water replacement or vitrification hypothesis), but the understanding of these is extremely complex (Cicerone and Soles, 2004). Overall, the correct selection of the viral stabilizer can have a profound impact on vaccine thermostability, 
which is especially more important in LAV and IN vaccines than in SUB vaccines, where a more complex API structure generally requires a more complex stabilizer formulation.

Acknowledgements. This research was supported by NFP grant "Research on innovative approaches and technological processes for the production of combinational vaccines and the generation of a seed lot system“"No. 0782/2013.

Supplementary information is available in the online version of the paper.

\section{References}

Albumedix website (2016): Retrieved from http://albumedix.com/ drug-formulation/drug-and-vaccine-stabilization/.

Alcock R, Cottingham M, Rollier C, Furze J, De Costa S, Hanlon M, Spencer A, Honeycutt J, Wyllie D, Gilbert S, Bregu M, Hill A., Sci. Transl. Med. 2, 19ra12, 2010. https://doi. org/10.1126/scitranslmed.3000490

Amorij J, Meulenaar J, Hinrichs W, Stegmann T, Huckriede A, Coenen F, Frijlink H., Vaccine 25, 6447-6457, 2007. https://doi.org/10.1016/j.vaccine.2007.06.054

Andrianov A, Decollibus D, Marin A, Webb A, Griffin Y., J. Pharm. Sci. 100, 1436-1443, 2011. https://doi.org/10.1002/ jps. 22367

Baker H and Ridley R., Brain Res. Bull. 40, 237-244, 1996. https:// doi.org/10.1016/0361-9230(96)00162-1

Barth R, Bijok U, Grushkau H, Smerdel J, Vodopija J., Lancet 1, 700, 1983. https://doi.org/10.1016/S0140-6736(83)91984-0

Beg S, Samad A, Nazish I, Sultana R, Rahman M, Ahmad M, Akbar M., Curr. Drug Targets 14, 123-137, 2013. https://doi. org/10.2174/138945013804806523

Braun L, Tyagi A, Perkins S, Carpenter J, Sylvester D, Guy M, Kristensen D, Chen D., Vaccine 27, 72-79, 2009a. https://doi. org/10.1016/j.vaccine.2008.10.027

Braun L, Jezek J, Peterson S, Tyagi A, Perkins S, Sylvester D, Guy M, Lal M, Priddy S, Plzak H, Kristensen D, Chen D., Vaccine 27, 4609-4614, 2009b. https://doi.org/10.1016/j. vaccine.2009.05.069

Burger J, Cape S, Braun C, McAdams D, Best J, Bhagwat P, Pathak P, Rebits L, Sievers R., J. Aerosol. Med. Pulm. Drug Deliv. 21, 25-34, 2008. https://doi.org/10.1089/jamp.2007.0658

Causer K (2005): Retrieved from http://www.docstoc.com/ docs/133429891/When-the-Cold-Chain-is-breachedrisk-assessment-LMC-LIVE

Chen B, Bautista R, Yu K, Zapata G, Mulkerrin M, Chamow S., Pharm. Res. 20, 1952-1960, 2003. https://doi.org/10.1023/ B:PHAM.0000008042.15988.c0

Chen D, Kristensen D., Expert. Rev. Vaccines 8, 547-557, 2009. https://doi.org/10.1586/erv.09.20

Chen D, Kapre S, Goel A, Suresh K, Beri S, Hickling J, Jensen J, Lal M, Preaud J, Laforce M, Kristensen D., Vaccine 28, 5093-5099. 2010. https://doi.org/10.1016/j. vaccine.2010.04.112
Chen X, Fernando G, Crichton M, Flaim C, Yukiko S, Fairmaid E, Corbett H, Primiero CA, Ansaldo A, Frazer I, Brown L, Kendall M., J. Control Release 152, 349-355, 2011. https:// doi.org/10.1016/j.jconrel.2011.02.026

Cicerone M, Soles C., Biophys. J. 86, 3836-3845, 2004. https://doi. org/10.1529/biophysj.103.035519

Cicerone M, Douglas J., Soft. Matter 8, 2983-2991, 2012. https:// doi.org/10.1039/c2sm06979b

Clapp T, Siebert P, Chen D, Jones Braun L., J. Pharm. Sci. 100, 388401, 2011. https://doi.org/10.1002/jps.22284

Crainic R, Wu R, Otelea D, Georgescu MM, Delpeyroux F, Guillot S, Balanant J, Tardy-Panit M., Dev. Biol. Stand 87, 161166, 1996.

de Jonge J, Amorij J, Hinrichs W, Wilschut J, Huckriede A, Frijlink H., Eur. J. Pharm. Sci. 32, 33-44, 2007. https://doi. org/10.1016/j.ejps.2007.05.112

Dhere R, Yeolekar L, Kulkarni P, Menon R, Vaidya V, Ganguly M, Tyagi P, Barde P, Jadhav S. Vaccine 29 (Suppl. 1), A16-21, 2011. https://doi.org/10.1016/j.vaccine.2011.04.119

Dorea J, Farina M, Rocha J., J. Appl. Toxicol. 33,700-711, 2013. https://doi.org/10.1002/jat.2855

Elshabrawy H, Erickson T, Prabhakar B., Rev. Med. Virol. 25, 241253, 2015. https://doi.org/10.1002/rmv.1841

European Agency for the Evaluation of Medicinal products (2009): Retrieved from http://www.ema.europa.eu/docs/ en_GB/document_library/Scientific_guideline/2009/09/ WC500003717.pdf

Fineberg H. N. Engl. J. Med. 370, 1335-1342, 2014. https://doi. org/10.1056/NEJMra1208802

Food and Drugs Administration (2013): Retrieved from http:// www.cdc.gov/vaccines/hcp/patient-ed/conversations/ downloads/vacsafe-thimerosal-color-office.pdf

Freire M, Mann G, Marchevsky R, Yamamura A, Almeida L, Jabor A, Malachias J, Coutinho E, Galler R., Vaccine 23, 2501-2512, 2005. https://doi.org/10.1016/j.vaccine.2004.10.035

Fujita Y, Taguchi H., Expert Rev. Vaccines 12, 809-819, 2013. https:// doi.org/10.1586/14760584.2013.811208

Garcia A, De Sanctis J., APMIS 122, 257-267, 2014. https://doi. org/10.1111/apm.12143

Garmise R, Staats H, Hickey A., AAPS Pharm. Sci. Tech. 8, 1-10, 2007. https://doi.org/10.1208/pt0804081

Geeraedts F, Saluja V, ter Veer W, Amorij JP, Frijlink HW, Wilschut J, Hinrichs WL, Huckriede A., AAPS J. 12, 215-222, 2010. https://doi.org/10.1208/s12248-010-9179-Z

Georgitis J, Fasano M., Curr. Allergy Rep. 1, 11-17, 2001. https:// doi.org/10.1007/s11882-001-0091-6

Golovanov A, Hautbergue G, Wilson S, Lian L., J. Am. Chem. Soc. 126, 8933-939, 2004. https://doi.org/10.1021/ja049297h

Global Grand Challenges website (2016): Retrieved from http:// gcgh.grandchallenges.org/challenge/prepare-vaccinesdo-not-require-refrigeration

Guy B, Barrere B, Malinowski C, Saville M, Teyssou R, Lang J., Vaccine 29, 7229-7241, 2011. https://doi.org/10.1016/j. vaccine.2011.06.094

Hamouda T, Chepurnov A, Mank N, Knowlton J, Chepurnova T, Myc A, Sutcliffe J, Baker J., Hum. Vaccin. 6, 585-594, 2010. https://doi.org/10.4161/hv.6.7.11818 
Health Canada (2010): Retrieved from http://www.hc-sc.gc.ca/ dhp-mps/alt_formats/pdf/prodpharma/legislation/ interimorders-arretesurgence/prodinfo-vaccin-eng.pdf

Jamil R, Taqavian M, Sadigh Z, Shahkarami M, Esna-Ashari F, Hamkar R, Hosseini S, Hatami A., J. Virol. Methods 199, 35-38, 2014. https://doi.org/10.1016/j.jviromet.2013.12.020

Jamil Z, Waheed Y, Durrani T., Asian Pac. J. Trop. Med. 9, 626-629, 2016. https://doi.org/10.1016/j.apjtm.2016.05.020

Jezek J, Chen D, Watson L, Crawford J, Perkins S, Tyagi A, JonesBraun L., Hum Vaccin. 5, 529-535, 2009. https://doi. org $/ 10.4161 /$ hv.5.8.8600

Johns Hopkins University (2007): Retrieved from http://pages. jh.edu/news_info/news/home07/may07/rotaviru.html

Kammer A, Amacker M, Rasi S, Westerfeld N, Gremion C, Neuhaus D, Zurbriggen R., Vaccine 25, 7065-7074, 2007. https:// doi.org/10.1016/j.vaccine.2007.07.052

Kaushik J, Bhat R., J. Biol. Chem. 278, 26458-26465, 2003. https:// doi.org/10.1074/jbc.M300815200

Kim Y, Quan F, Compans R, Kang S, Prausnitz M., AAPS Pharm Sci, Tech, 11, 1193-1201, 2010. https://doi.org/10.1208/ s12249-010-9471-3

King K, Paterson M, Green S., Pediatrics 131, 154-156, 2013. https:// doi.org/10.1542/peds.2012-2976

Kissmann J, Ausar SF, Rudolph A, Braun C, Cape S, Sievers R, Federspiel M, Joshi S, Middaugh C., Hum. Vaccin. 4, 350-359, 2008. https://doi.org/10.4161/hv.4.5.5863

Kristensen D, Chen D, Cummings R., Vaccine 29, 7122-7124, 2011. https://doi.org/10.1016/j.vaccine.2011.05.070

Kumru O, Joshi S, Smith D, Middaugh C, Prusik T, Volkin D., Biologicals 42, 237-259, 2014. https://doi.org/10.1016/j. biologicals.2014.05.007

Le Tallec D, Doucet D, Elouahabi A, Harvengt P, Deschuyteneer M, Deschamps M., Hum. Vaccin. 5, 467-474, 2009. https:// doi.org/10.4161/hv.8485

Lee S, Belitsky B, Brinker J, Kerstein K, Brown D, Clements J, Keusch G, Tzipori S, Sonenshein A, Herrmann J., Clin, Vaccine Immunol, 17, 1647-1655, 2010. https://doi.org/10.1128/ CVI.00135-10

Liska V, Bigert S, Bennett P, Olsen D, Chang R, Burke C., J. Immune Based Ther. Vaccines 5, 4, 2007. https://doi. org/10.1186/1476-8518-5-4

Luke J, Carnes A, Sun P, Hodgson C, Waugh D, Williams J., J. Biotechnol. 151, 242-250, 2011. https://doi.org/10.1016/j. jbiotec.2010.12.011

Maa Y, Ameri M, Shu C, Payne LG, Chen D., J. Pharm. Sci. 93, 1912-1923, 2004. https://doi.org/10.1002/jps.20104

Makidon P, Bielinska A, Nigavekar S, Janczak K, Knowlton J, Scott A, Mank N, Cao Z, Rathinavelu S, Beer M, Wilkinson J, Blanco L, Landers J, Baker J., PLoS One 3, e2954, 2008. https://doi.org/10.1371/journal.pone.0002954

Matthias D, Robertson J, Garrison M, Newland S, Nelson C., Vaccine 25, 3980-3986, 2007. https://doi.org/10.1016/j. vaccine.2007.02.052

Mohan T, Verma P, Rao D., Indian J, Med, Res, 138, 779-795, 2013.

Monath T, Lee C, Julander J, Brown A, Beasley D, Watts D, Hayman E, Guertin P, Makowiecki J, Crowell J, Levesque P, Bowick G, Morin M, Fowler E, Trent D., Vaccine 28, 3827-3840, 2010. https://doi.org/10.1016/j.vaccine.2010.03.023
Morefield G., AAPS J. 13, 191-200, 2011. https://doi.org/10.1208/ s12248-011-9261-1

Offit P, Jew R., Pediatrics 112, 1394-1397, 2003. https://doi. org/10.1542/peds.112.6.1394

Ohtake S, Martin RA, Yee L, Chen D, Kristensen DD, LechugaBallesteros D, Truong-Le V., Vaccine 28, 1275-8124, 2009. https://doi.org/10.1016/j.vaccine.2009.11.024

Patois E, Capelle MA, Gurny R, Arvinte T., Vaccine 29, 7404-7413, 2011. https://doi.org/10.1016/j.vaccine.2011.07.067

Perrin P, Morgeaux S., Biologicals 23, 207-211, 1995. https://doi. org/10.1006/biol.1995.0034

Plotkin S., Nat. Med .11 (Suppl. 4), S5-11, 2005. https://doi. org $/ 10.1038 / \mathrm{nm} 1209$

Plotkin S., Proc. Natl. Acad. Sci. USA 111, 12283-12287, 2014. https://doi.org/10.1073/pnas.1400472111

Rappuoli R., Curr. Opin. Microbiol. 3, 445-450, 2000. https://doi. org/10.1016/S1369-5274(00)00119-3

Rimmelzwaan G, Sutter G., Expert. Rev. Vaccines 8 447-454, 2009. https://doi.org/10.1586/erv.09.4

Rodriguez-Limas W, Sekar K, Tyo K., Curr. Opin. Biotechnol. 24, 1089-1093, 2013. https://doi.org/10.1016/j. copbio.2013.02.008

Rota P., Global measles and rubella management meeting. $15-17$ March, Geneva, Switzerland, 2011.

Rottem M, Shoenfeld Y., Curr. Opin. Otolaryngol. Head Neck Surg. 12, 223-231, 2004. https://doi.org/10.1097/01. $\underline{\text { moo.0000122312.13359.eb }}$

Saluja V, Amorij J, Kapteyn J, de Boer A, Frijlink H, Hinrichs W., J. Control Release 144, 127-133, 2010. https://doi. org/10.1016/j.jconrel.2010.02.025

Schlehuber L, McFadyen I, Shu Y, Carignan J, Duprex W, Forsyth W, Ho J, Kitsos C, Lee G, Levinson D, Lucier S, Moore C, Nguyen N, Ramos J, Weinstock B, Zhang J, Monagle J, Gardner C, Alvarez J., Vaccine 29, 5031-5039, 2011. https://doi.org/10.1016/j.vaccine.2011.04.079

Shank-Retzlaff M, Zhao Q, Anderson C, Hamm M, High K, Nguyen M, Wang F, Wang N, Wang B, Wang Y, Washabaugh M, Sitrin R, Shi L., Hum. Vaccin. 2, 147-154, 2006. https:// doi.org/10.4161/hv.2.4.2989

Shiomi H, Urasawa T, Urasawa S., Jpn. J. Infect. Dis. 56, 70-72, 2003.

Shukla D, Trout B., J. Phys. Chem. B. 114, 13426-13438, 2010. https://doi.org/10.1021/jp108399g

Stabilitech (2011): Retrieved from http://www.stabilitech.com/sites/ default/files/Stabilitech_NonConf_Aug2011.pdf

Stabilitech (2012): Retrieved from http://www.ntnv.org/wp-content/ uploads/2012/10/1520-Drew.pdf

Takaku K et al., Biken J. 11, 26-39, 1968.

Tian F, Middaugh C, Offerdahl T, Munson E, Sane S, Rytting J., Int. J. Pharm. 335, 20-31, 2007. https://doi.org/10.1016/j. ijpharm.2006.10.037

Toriniwa H, Komiya T., Vaccine 4; 26, 3680-3689, 2008. https://doi. org/10.1016/j.vaccine.2008.04.076

Vaxart (2016): Retrieved from http://www.vaxart.com/TechPlatformScience.html

VBI vaccines (2016): Retrieved from http://www.vbivaccines.com/ technology/thermostable-platform/

Wade A, Tucker H., J. Nutr. Biochem. 9, 308-315, 1998. https://doi. org/10.1016/S0955-2863(98)00022-9 
Walter T, Ren J, Tuthill T, Rowlands D, Stuart D, Fry E., J. Virol. Methods 185, 166-170, 2012. https://doi.org/10.1016/j. jviromet.2012.06.014

World Health Organization (2013): Retrieved from http://www. who.int/biologicals/vaccines/TRS_978_Annex_3. pdf?ua $=1$
Wiggan O, Livengood J, Silengo S, Kinney R, Osorio J, Huang C, Stinchcomb D., Vaccine 29, 7456-7462, 2011. https://doi. org/10.1016/j.vaccine.2011.07.054

Wirkas T, Toikilik S, Miller N, Morgan C, Clements C., Vaccine 25, 691-697, 2007. https://doi.org/10.1016/j. vaccine.2006.08.028 


\title{
Supplementary information
}

\section{REVIEW}

\section{Viral vaccine stabilizers: status and trends}

\author{
F. M. C. CARDOSO ${ }^{1}$, D. PETROVAJOVÁ ${ }^{1}$, T. HORŇÁKOVÁ 1,2
}

${ }^{1}$ Research and Development Department, Imuna Pharm a.s., Jarková 17, 08222 Šarišské Michalany, Slovak Republic;

${ }^{2}$ Olomouc University Social Health Institute (OUSHI), Olomouc, Czech Republic

Received November 11, 2016; accepted January 4, 2017

Supplementary Table S3. Overview of currently licensed vaccines representatives (the vaccines in this list are categorized by vaccine type, depicting available data from supplementary package insert, product monograph or package insert)

\begin{tabular}{|c|c|c|c|c|c|c|c|c|c|}
\hline & $\begin{array}{l}\text { Product } \\
\text { name }\end{array}$ & Company & Stabilizers & Pres/adm ${ }^{1}$ & FPPS $^{2}$ & Storage & $\begin{array}{l}\text { Shelf-life } \\
\text { (months) }\end{array}$ & $\begin{array}{l}\text { Thermosta- } \\
\text { bility }\end{array}$ & Ref \\
\hline \multicolumn{10}{|c|}{ LIVE ATTENUATED } \\
\hline Adenovirus & $\begin{array}{l}\text { No trade- } \\
\text { mark name }\end{array}$ & $\begin{array}{l}\text { Barr Labs/ Teva } \\
\text { Pharmaceuticals } \\
\text { (USA) }\end{array}$ & $\begin{array}{l}\text { monosodium } \\
\text { glutamate, HSA } \\
\text { plasdone C, } \\
\text { sucrose, D-man- } \\
\text { nose, D-fructose, } \\
\text { dextrose }\end{array}$ & tablet (oral) & WI- $38^{5}$ & $\begin{array}{l}2-8^{\circ} \mathrm{C} \\
\left(\text { FrSen }^{6}\right)\end{array}$ & 48 & $\mathrm{~N} / \mathrm{A}^{7}$ & $\mathrm{SPC}^{8}$ \\
\hline $\begin{array}{l}\text { Influenza } \\
\text { (seasonal) }\end{array}$ & FluMist & $\begin{array}{l}\text { Med Immune } \\
\text { (USA) }\end{array}$ & $\begin{array}{l}\text { monosodium } \\
\text { glutamate, hy- } \\
\text { drolyzed porcine } \\
\text { gelatin, arginine, } \\
\text { sucrose }\end{array}$ & liquid (nasal) & SPFCE $^{9}$ & $\begin{array}{l}2-8^{\circ} \mathrm{C} \\
\text { (FrSen) }\end{array}$ & 4,5 & $12 \mathrm{~h}\left(25^{\circ} \mathrm{C}\right)$ & SPC \\
\hline $\begin{array}{l}\text { Influenza } \\
\text { (pandemic) }\end{array}$ & $\begin{array}{l}\text { NasoVac } \\
\text { (H1N1) }\end{array}$ & $\mathrm{SII}^{10}$ (India) & $\begin{array}{l}\text { gelatin, sorbitol, } \\
\text { L-alanine, L- } \\
\text { histidine, tricine, } \\
\text { L-arginine hydro- } \\
\text { chloride, LAH }{ }^{11}\end{array}$ & $\begin{array}{l}\text { lyophilized } \\
\text { (nasal) }\end{array}$ & SPFCE & $2-8^{\circ} \mathrm{C}$ & 9 & N/A & $\begin{array}{l}\text { SPC, Dhere } \\
\text { et al., } 2011\end{array}$ \\
\hline \multirow[t]{2}{*}{ Measles } & Attenuvax & Merck (USA) & $\begin{array}{l}\text { hydrolyzed gela- } \\
\text { tin, HSA, sorbitol, } \\
\text { sucrose }\end{array}$ & $\begin{array}{l}\text { lyophilized } \\
\left(\mathrm{SC}^{12}\right)\end{array}$ & $\mathrm{CEF}^{13}$ & $2-8^{\circ} \mathrm{C}$ & 24 & $\begin{array}{l}8 \text { months } \\
\left(20-25^{\circ} \mathrm{C}\right), \\
4 \text { weeks } \\
\left(37^{\circ} \mathrm{C}\right) \text {, } \\
\text { reconsti- } \\
\text { tuted: loss of } \\
50 \% \text { potency } \\
\text { in } 1 \mathrm{~h}(20- \\
\left.25^{\circ} \mathrm{C}\right) \text {, all } \\
\text { potency in } 1 \\
\mathrm{~h}\left(37^{\circ} \mathrm{C}\right)\end{array}$ & SPC \\
\hline & $\mathrm{M}-\mathrm{Vac}$ & $\begin{array}{l}\text { SII } \\
\text { (India) }\end{array}$ & $\begin{array}{l}\text { hydrolyzed gela- } \\
\text { tin, LAH, tricine, } \\
\text { alanine, arginine, } \\
\text { histidine }\end{array}$ & $\begin{array}{l}\text { lyophilized } \\
\left(\mathrm{SC} / \mathrm{IM}^{14}\right)\end{array}$ & $\mathrm{HDC}^{15}$ & $2-8^{\circ} \mathrm{C}$ & 24 & N/A & SPC \\
\hline
\end{tabular}




\begin{tabular}{|c|c|c|c|c|c|c|c|c|c|}
\hline & $\begin{array}{l}\text { Product } \\
\text { name }\end{array}$ & Company & Stabilizers & Pres/adm ${ }^{1}$ & FPPS $^{2}$ & Storage & $\begin{array}{l}\text { Shelf-life } \\
\text { (months) }\end{array}$ & $\begin{array}{l}\text { Thermosta- } \\
\text { bility }\end{array}$ & Ref \\
\hline & $\begin{array}{l}\text { Measles Vac- } \\
\text { cine }\end{array}$ & $\begin{array}{l}\text { Biofarma (Indo- } \\
\text { nesia) }\end{array}$ & $\begin{array}{l}\text { gelatin, L- } \\
\text { cysteine, D- } \\
\text { sorbitol, lactose } \\
\text { monohydrate }\end{array}$ & $\begin{array}{l}\text { lyophilized } \\
\text { (SC) }\end{array}$ & SPFCE & $2-8^{\circ} \mathrm{C}$ & 24 & N/A & SPC \\
\hline & $\begin{array}{l}\text { Measles Vac- } \\
\text { cine }\end{array}$ & $\begin{array}{l}\text { GPO }^{16} \text { (Thai- } \\
\text { land) }\end{array}$ & HSA & $\begin{array}{l}\text { lyophilized } \\
\text { (SC/IM) }\end{array}$ & $\mathrm{CEF}$ & $2-8^{\circ} \mathrm{C}$ & 36 & $\mathrm{~N} / \mathrm{A}$ & SPC \\
\hline & $\begin{array}{l}\text { Measles Vac- } \\
\text { cine }\end{array}$ & $\begin{array}{l}\text { Institute of } \\
\text { Immunology } \\
\text { (Croatia) }\end{array}$ & $\begin{array}{l}\mathrm{LAH} \text {, gelatin, L- } \\
\text { arginine HCL, L- } \\
\text { alanine, sorbitol, } \\
\text { maltose }\end{array}$ & $\begin{array}{l}\text { lyophilized } \\
\text { (SC) }\end{array}$ & $\mathrm{HDC}$ & $2-8^{\circ} \mathrm{C}$ & 24 & N/A & SPC \\
\hline & Rouvax & $\begin{array}{l}\text { Sanofi Pasteur } \\
\text { (France) }\end{array}$ & HSA, lactose & $\begin{array}{l}\text { lyophilized } \\
\text { (SC/IM) }\end{array}$ & CEF & $2-8^{\circ} \mathrm{C}$ & 36 & N/A & SPC \\
\hline & Rudivax & $\begin{array}{l}\text { Sanofi Pasteur } \\
\text { (France) }\end{array}$ & $\mathrm{N} / \mathrm{A}$ & $\begin{array}{l}\text { lyophilized } \\
\text { (SC/IM) }\end{array}$ & $\mathrm{MRC}-5^{17}$ & $2-8^{\circ} \mathrm{C}$ & 24 & $\begin{array}{l}\text { reconstitut- } \\
\text { ed: } 8 \text { h }\left(2-8^{\circ}\right. \\
\text { C), } 4 \text { weeks } \\
\left(37^{\circ} \mathrm{C}\right)\end{array}$ & SPC \\
\hline \multirow[t]{2}{*}{ Polio } & $\begin{array}{l}\text { TOPV }{ }^{18} \text { Polio } \\
\text { Sabin }\end{array}$ & $\begin{array}{l}\text { GSK }^{19} \\
\text { (Belgium) }\end{array}$ & $\begin{array}{l}\text { L-arginine, } \\
\text { polysorbate } 80\end{array}$ & liquid (oral) & MRC-5 & frozen & 18 & $\begin{array}{l}6 \text { months } \\
\left(2-8^{\circ} \mathrm{C}\right)\end{array}$ & SPC \\
\hline & $\begin{array}{l}\text { TOPV: Pol- } \\
\text { ioral }\end{array}$ & Novartis (Italy) & $\mathrm{LAH}$ & liquid (oral) & Vero & frozen & 24 & $\mathrm{~N} / \mathrm{A}$ & SPC \\
\hline \multirow[t]{2}{*}{ Rotavirus } & Rotarix & GSK (Belgium) & $\begin{array}{l}\text { amino acids, } \\
\text { dextran, sorbitol, } \\
\text { sucrose }\end{array}$ & $\begin{array}{l}\text { lyophilized } \\
\text { (oral) }\end{array}$ & Vero & $2-8^{\circ} \mathrm{C}$ & 36 & $\begin{array}{l}\text { lyophilized: } \\
7 \text { days } \\
\left(20^{\circ} \mathrm{C}\right) \text {; re- } \\
\text { constituted: } \\
24 \mathrm{~h}\left(2-8^{\circ} \mathrm{C}\right)\end{array}$ & SPC \\
\hline & Rotateq & Merck (USA) & $\begin{array}{l}\text { sucrose, } \\
\text { polysorbate } 80\end{array}$ & $\begin{array}{l}\text { lyophilized } \\
\text { (oral) }\end{array}$ & Vero & $2-8^{\circ} \mathrm{C}$ & 24 & $\begin{array}{l}48 \mathrm{~h} \\
\left(9-25^{\circ} \mathrm{C}\right), 12 \\
\mathrm{~h}\left(26-30^{\circ} \mathrm{C}\right)\end{array}$ & SPC \\
\hline \multirow[t]{2}{*}{ Rubella } & $\begin{array}{l}\text { Rubella vac- } \\
\text { cine }\end{array}$ & SII (India) & $\mathrm{N} / \mathrm{A}$ & $\begin{array}{l}\text { lyophilized } \\
\text { (SC) }\end{array}$ & MRC-5 & $2-8^{\circ} \mathrm{C}$ & 24 & $\mathrm{~N} / \mathrm{A}$ & SPC \\
\hline & Meruvax II & Merck (USA) & $\begin{array}{l}\text { sorbitol, sucrose, } \\
\text { hydrolyzed gela- } \\
\text { tin, HSA, FBS }{ }^{20}\end{array}$ & $\begin{array}{l}\text { lyophilized } \\
\text { (SC) }\end{array}$ & WI-38 & $2-8^{\circ} \mathrm{C}$ & 24 & $\begin{array}{l}\text { reconsti- } \\
\text { tuted: } 6-8 \mathrm{~h} \\
\left(20-25^{\circ} \mathrm{C}\right)\end{array}$ & SPC \\
\hline Smallpox & ACAM2000 & $\begin{array}{l}\text { Sanofi Pasteur } \\
\text { (USA) }\end{array}$ & HSA, mannitol & $\begin{array}{l}\text { lyophilized } \\
\left(\mathrm{PC}^{21}\right)\end{array}$ & Vero & frozen & 84 & $\begin{array}{l}\text { lyophilized: } \\
18 \text { months } \\
\left(2^{\circ}-8^{\circ} \mathrm{C}\right) \text {; re- } \\
\text { constituted: } \\
6-8 \text { hours } \\
\left(20^{\circ}-25^{\circ} \mathrm{C}\right) \text {, } \\
1 \text { month }\left(2^{\circ}-\right. \\
\left.8^{\circ} \mathrm{C}\right)\end{array}$ & SPC \\
\hline Varicella & Varilix & GSK (Belgium) & $\begin{array}{l}\text { amino acids, } \\
\text { lactose, mannitol, } \\
\text { sorbitol }\end{array}$ & $\begin{array}{l}\text { lyophilized } \\
\text { (SC) }\end{array}$ & MRC-5 & $2-8^{\circ} \mathrm{C}$ & 24 & $\begin{array}{l}\text { reconsti- } \\
\text { tuted: } 8 \mathrm{~h} \\
\left(2-8^{\circ} \mathrm{C}\right), 1.5 \\
\mathrm{~h}\left(25^{\circ} \mathrm{C}\right)\end{array}$ & SPC \\
\hline & Varivax & Merck (USA) & $\begin{array}{l}\text { gelatin, monoso- } \\
\text { dium L-glutamate, } \\
\text { sucrose }\end{array}$ & $\begin{array}{l}\text { lyophilized } \\
\text { (SC) }\end{array}$ & MRC-5 & frozen & 24 & $\begin{array}{l}\text { lyophilized: } \\
24 \text { months } \\
\left(2-8^{\circ} \mathrm{C}\right) \text {, } \\
4 \text { months } \\
\left(15^{\circ} \mathrm{C}\right) \text {; re- } \\
\text { constituted: } \\
6 \mathrm{~h}\left(27^{\circ} \mathrm{C}\right)\end{array}$ & SPC 50 \\
\hline Zoster & Zostavax & Merck (USA) & $\begin{array}{l}\text { hydrolyzed } \\
\text { porcine gelatin, } \\
\text { monosodium L- } \\
\text { glutamate, sucrose }\end{array}$ & $\begin{array}{l}\text { lyophilized } \\
\text { (SC) }\end{array}$ & MRC-5 & frozen & 18 & $\begin{array}{l}\text { lyophilized: } \\
72 \mathrm{~h}\left(2-8^{\circ} \mathrm{C}\right)\end{array}$ & SPC \\
\hline \multicolumn{10}{|c|}{ INACTIVATED } \\
\hline Hepatitis A & Vaqta & Merck (USA) & $\begin{array}{l}\text { aluminium (ad- } \\
\text { juvant), sodium } \\
\text { borate }\end{array}$ & liquid (IM) & MRC-5 & $\begin{array}{l}2-8^{\circ} \mathrm{C} \\
\text { (FrSen) }\end{array}$ & 36 & $\begin{array}{l}\text { lyophilized: } \\
3 \text { months } \\
\left(28^{\circ} \mathrm{C}\right) ; \\
12 \text { months } \\
\left(37^{\circ} \mathrm{C}\right)\end{array}$ & SPC \\
\hline
\end{tabular}




\begin{tabular}{|c|c|c|c|c|c|c|c|c|c|}
\hline & $\begin{array}{l}\text { Product } \\
\text { name }\end{array}$ & Company & Stabilizers & Pres/adm ${ }^{1}$ & FPPS $^{2}$ & Storage & $\begin{array}{l}\text { Shelf-life } \\
\text { (months) }\end{array}$ & $\begin{array}{l}\text { Thermosta- } \\
\text { bility }\end{array}$ & Ref \\
\hline \multirow{7}{*}{$\begin{array}{l}\text { Influenza } \\
\text { (seasonal } \\
\text { Influenza } \\
\text { (seasonal) }\end{array}$} & Optaflu & Novartis (USA) & N/A & liquid (IM) & $\begin{array}{l}\text { suM- } \\
\text { DCK }^{22}\end{array}$ & $\begin{array}{l}2-8^{\circ} \mathrm{C} \\
\text { (FrSen) }\end{array}$ & 12 & N/A & SPC \\
\hline & Fluarix & GSK (Germany) & N/A & liquid (IM) & SPFCE & $\begin{array}{l}2-8^{\circ} \mathrm{C} \\
\text { (FrSen) }\end{array}$ & 12 & $\begin{array}{l}1 \text { freeze/ } \\
\text { thaw cycle: } \\
\text { no effect, } \\
12 \mathrm{w}\left(20^{\circ} \mathrm{C}\right)\end{array}$ & $\begin{array}{l}\text { SPC Patois } \\
\text { et al., } 2011\end{array}$ \\
\hline & Flulaval & $\begin{array}{l}\text { ID Biomed/ } \\
\text { GSK (Canada) }\end{array}$ & N/A & liquid (IM) & SPFCE & $\begin{array}{l}2-8^{\circ} \mathrm{C} \\
\text { (FrSen) }\end{array}$ & 12 & $\mathrm{~N} / \mathrm{A}$ & SPC \\
\hline & Agriflu & $\begin{array}{l}\text { Novartis (Can- } \\
\text { ada) }\end{array}$ & $\begin{array}{l}\text { potassium, sodi- } \\
\text { um, magnessium } \\
\text { and calcium salts }\end{array}$ & liquid (IM) & SPFCE & $\begin{array}{l}2-8^{\circ} \mathrm{C} \\
\text { (FrSen) }\end{array}$ & 12 & N/A & SPC \\
\hline & Fluzone & $\begin{array}{l}\text { Sanofi Pasteur } \\
\text { (USA) }\end{array}$ & $\begin{array}{l}\text { gelatin, Triton } \\
\mathrm{X}-100\end{array}$ & liquid (IM) & SPFCE & $\begin{array}{l}2-8^{\circ} \mathrm{C} \\
\text { (FrSen) }\end{array}$ & N/A & N/A & SPC \\
\hline & Afluria & $\begin{array}{l}\text { CSL limited } \\
\text { (Australia) }\end{array}$ & $\begin{array}{l}\text { sodium, potas- } \\
\text { sium and calcium } \\
\text { salts }\end{array}$ & liquid (IM) & SPFCE & $\begin{array}{l}2-8^{\circ} \mathrm{C} \\
\text { (FrSen) }\end{array}$ & 12 & N/A & SPC \\
\hline & Fluvax & $\begin{array}{l}\text { CSL limited } \\
\text { (Australia) }\end{array}$ & $\begin{array}{l}\text { sodium, potas- } \\
\text { sium and calcium } \\
\text { salts }\end{array}$ & $\begin{array}{l}\text { liquid (IM/ } \\
\text { deep SC) }\end{array}$ & SPFCE & $\begin{array}{l}2-8^{\circ} \mathrm{C} \\
\text { (FrSen) }\end{array}$ & N/A & N/A & SPC \\
\hline \multirow[t]{14}{*}{$\begin{array}{l}\text { Influenza } \\
\text { (pandemic) }\end{array}$} & $\mathrm{H} 5 \mathrm{~N} 1$ & $\begin{array}{l}\text { Sanofi Pasteur } \\
\text { (USA) }\end{array}$ & $\begin{array}{l}\text { porcine gelatin, } \\
\text { sucrose }\end{array}$ & liquid (IM) & SPFCE & $\begin{array}{l}2-8^{\circ} \mathrm{C} \\
\text { (FrSen) }\end{array}$ & N/A & N/A & SPC \\
\hline & $\begin{array}{l}\text { Fluvirin } \\
(\mathrm{H} 1 \mathrm{~N} 1)\end{array}$ & Novartis (UK) & N/A & liquid (IM) & SPFCE & $\begin{array}{l}2-8^{\circ} \mathrm{C} \\
\text { (FrSen) }\end{array}$ & 6 & N/A & SPC \\
\hline & $\mathrm{H} 5 \mathrm{~N} 1$ & $\begin{array}{l}\text { ID Biomed/GSK } \\
\text { (Canada) }\end{array}$ & $\mathrm{ASO}^{23}$ (adjuvant) & liquid (IM) & SPFCE & $\begin{array}{l}2-8^{\circ} \mathrm{C} \\
\text { (FrSen) }\end{array}$ & 24 & N/A & SPC \\
\hline & 2009 H1N1 & $\begin{array}{l}\text { CSL limited } \\
\text { (Australia) }\end{array}$ & N/A & liquid (IM) & SPFCE & $\begin{array}{l}2-8^{\circ} \mathrm{C} \\
\text { (FrSen) }\end{array}$ & 12 & N/A & SPC \\
\hline & 2009 H1N1 & $\begin{array}{l}\text { MedImmune/ } \\
\text { AstraZeneca } \\
\text { (USA) }\end{array}$ & $\begin{array}{l}\text { sucrose, mono- } \\
\text { sodium gluta- } \\
\text { mate, hydrolyzed } \\
\text { porcine gelatin, } \\
\text { arginine }\end{array}$ & liquid (nasal) & SPFCE & $\begin{array}{l}2-8^{\circ} \mathrm{C} \\
\text { (FrSen) }\end{array}$ & 4,5 & N/A & SPC \\
\hline & $\begin{array}{l}\text { Focetria } \\
(2009 \mathrm{H} 1 \mathrm{~N} 1)\end{array}$ & Novartis (USA) & MF59 $^{24}$ (adjuvant) & liquid (IM) & SPFCE & $\begin{array}{l}2-8^{\circ} \mathrm{C} \\
\text { (FrSen) }\end{array}$ & N/A & N/A & SPC \\
\hline & 2009 H1N1 & $\begin{array}{l}\text { Sanofi Pasteur } \\
\text { (USA) }\end{array}$ & gelatin & liquid (IM) & SPFCE & $\begin{array}{l}2-8^{\circ} \mathrm{C} \\
\text { (FrSen) }\end{array}$ & 18 & N/A & SPC \\
\hline & $\begin{array}{l}\text { Humenza } \\
(\mathrm{H} 1 \mathrm{~N} 1)\end{array}$ & $\begin{array}{l}\text { Sanofi Pasteur } \\
\text { (France) }\end{array}$ & AF03 $3^{25}$ (adjuvant) & liquid (IM) & SPFCE & $\begin{array}{l}2-8^{\circ} \mathrm{C} \\
\text { (FrSen) }\end{array}$ & 6 & N/A & SPC \\
\hline & $\begin{array}{l}\text { Anflu } \\
(\mathrm{H} 5 \mathrm{~N} 1)\end{array}$ & Sinovac (China) & $\begin{array}{l}\mathrm{Al}(\mathrm{OH})_{3} \text { (adju- } \\
\text { vant) }\end{array}$ & liquid (IM) & SPFCE & $\begin{array}{l}2-8^{\circ} \mathrm{C} \\
\text { (FrSen) }\end{array}$ & 12 & N/A & SPC \\
\hline & $\begin{array}{l}\text { Arepanrix } \\
(\mathrm{H} 1 \mathrm{~N} 1)\end{array}$ & GSK (Belgium) & ASO3 (adjuvant) & liquid (IM) & SPFCE & $\begin{array}{l}2-8^{\circ} \mathrm{C} \\
\text { (FrSen) }\end{array}$ & 6 & $\begin{array}{l}50^{\circ} \mathrm{C} \text {, he- } \\
\text { magglutinin } \\
\text { stable for } 1 \mathrm{~h}\end{array}$ & $\begin{array}{l}\text { SPC Health } \\
\text { Canada, } \\
2010\end{array}$ \\
\hline & $\begin{array}{l}\text { Green } \\
\text { Flu-S (H1N1) }\end{array}$ & $\begin{array}{l}\text { Green Cross } \\
\text { (Korea) }\end{array}$ & N/A & liquid (IM) & SPFCE & $\begin{array}{l}2-8^{\circ} \mathrm{C} \\
\text { (FrSen) }\end{array}$ & 12 & N/A & SPC \\
\hline & Pandemrix & GSK (Germany) & AS03 (adjuvant) & liquid (IM) & SPFCE & $\begin{array}{l}2-8^{\circ} \mathrm{C} \\
\text { (FrSen) }\end{array}$ & 24 & N/A & SPC \\
\hline & $\begin{array}{l}\text { Panvax } \\
(\mathrm{H} 1 \mathrm{~N} 1)\end{array}$ & $\begin{array}{l}\text { CSL Limited } \\
\text { (Australia) }\end{array}$ & polysorbate 20 & liquid (IM) & SPFCE & $\begin{array}{l}2-8^{\circ} \mathrm{C} \\
\text { (FrSen) }\end{array}$ & 12 & N/A & SPC \\
\hline & $\begin{array}{l}\text { Panenza } \\
(\mathrm{H} 1 \mathrm{~N} 1)\end{array}$ & $\begin{array}{l}\text { Sanofi Pasteur } \\
\text { (France) }\end{array}$ & polysorbate 20 & liquid (IM) & SPFCE & $\begin{array}{l}2-8^{\circ} \mathrm{C} \\
\text { (FrSen) }\end{array}$ & 12 & N/A & SPC \\
\hline $\begin{array}{l}\text { Influenza } \\
\text { (pandemic) }\end{array}$ & $\begin{array}{l}\text { Celvapan } \\
(\mathrm{H} 1 \mathrm{~N} 1)\end{array}$ & Baxter (Austria) & polysorbate 80 & liquid (IM) & Vero & $\begin{array}{l}2-8^{\circ} \mathrm{C} \\
\text { (FrSen) }\end{array}$ & 12 & N/A & SPC \\
\hline \multirow[t]{2}{*}{$\begin{array}{l}\text { Japanese en- } \\
\text { cephalitis }\end{array}$} & Ixiaro & $\begin{array}{l}\text { NOVARTIS/ } \\
\text { Intercell (UK) }\end{array}$ & $\begin{array}{l}\mathrm{Al}(\mathrm{OH})_{3} \text { (adju- } \\
\text { vant), protamine } \\
\text { sulfate }\end{array}$ & liquid (IM) & Vero & $\begin{array}{l}2-8^{\circ} \mathrm{C} \\
\text { (FrSen) }\end{array}$ & 18 & N/A & SPC \\
\hline & JE-VAX & BIKEN (Japan) & gelatin & $\begin{array}{l}\text { lyophilized } \\
\text { (SC) }\end{array}$ & $\begin{array}{l}\text { mice } \\
\text { brains }\end{array}$ & $\begin{array}{l}2-8^{\circ} \mathrm{C} \\
\text { (FrSen) }\end{array}$ & 18 & $\begin{array}{l}\text { lyophilized: } \\
28 \text { weeks } \\
\left(22^{\circ} \mathrm{C}\right) \text {, } \\
1 \text { month } \\
\left(37^{\circ} \mathrm{C}\right) \text {, } \\
\text { reconsti- } \\
\text { tuted: } 8 \text { h } \\
\left(2-8^{\circ} \mathrm{C}\right)\end{array}$ & $\begin{array}{l}\text { SPC, } \\
\text { Takaku et } \\
\text { al., } 1968\end{array}$ \\
\hline
\end{tabular}




\begin{tabular}{|c|c|c|c|c|c|c|c|c|c|}
\hline & $\begin{array}{l}\text { Product } \\
\text { name }\end{array}$ & Company & Stabilizers & Pres/adm ${ }^{1}$ & FPPS $^{2}$ & Storage & $\begin{array}{l}\text { Shelf-life } \\
\text { (months) }\end{array}$ & $\begin{array}{l}\text { Thermosta- } \\
\text { bility }\end{array}$ & Ref \\
\hline \multirow[t]{3}{*}{ Polio } & Imovax & $\begin{array}{l}\text { Sanofi Pasteur } \\
\text { (France) }\end{array}$ & HSA & $\begin{array}{l}\text { lyophilized } \\
\text { (IM) }\end{array}$ & MRC-5 & $\begin{array}{l}2-8^{\circ} \mathrm{C} \\
\text { (FrSen) }\end{array}$ & 36 & N/A & SPC \\
\hline & IPOL & $\begin{array}{l}\text { Sanofi Pasteur } \\
\text { (France) }\end{array}$ & $\begin{array}{l}\text { 2-4 phenoxy etha- } \\
\text { nol, formaldehyde }\end{array}$ & $\begin{array}{l}\text { lyophilized } \\
\text { (IM/ SC) }\end{array}$ & $\mathrm{mVero}^{26}$ & $\begin{array}{l}2-8^{\circ} \mathrm{C} \\
\text { (FrSen) }\end{array}$ & 24 & N/A & SPC \\
\hline & Poliorix & GSK (Belgium) & $\begin{array}{l}\text { aminoacids, } \\
\text { 2-phenoxyeth- } \\
\text { anol, formalde- } \\
\text { hyde, polysorbate } \\
80\end{array}$ & liquid (IM) & Vero & $\begin{array}{l}2-8^{\circ} \mathrm{C} \\
\text { (FrSen) }\end{array}$ & 36 & N/A & SPC \\
\hline \multirow[t]{5}{*}{ Rabies } & Havrix & GSK (Belgium) & $\begin{array}{l}\mathrm{Al}(\mathrm{OH})_{3} \text { (ad- } \\
\text { juvant), amino } \\
\text { acids, polysorb- } \\
\text { ate } 20\end{array}$ & liquid (IM) & MRC-5 & $\begin{array}{l}2-8^{\circ} \mathrm{C} \\
\text { (FrSen) }\end{array}$ & 36 & $\begin{array}{l}\text { lyophilized: } \\
3 \text { weeks }\left(37^{\circ}\right. \\
\text { C) }\end{array}$ & SPC \\
\hline & Imovax & $\begin{array}{l}\text { Sanofi Pasteur } \\
\text { (France) }\end{array}$ & HSA & $\begin{array}{l}\text { lyophilized } \\
\text { (IM) }\end{array}$ & MRC-5 & $2-8^{\circ} \mathrm{C}$ & N/A & N/A & SPC \\
\hline & RabAvert & $\begin{array}{l}\text { Novartis (Ger- } \\
\text { many) }\end{array}$ & $\begin{array}{l}\text { gelatin, HSA, } \\
\text { glutamate, sodium } \\
\text { EDTA }\end{array}$ & $\begin{array}{l}\text { lyophilized } \\
\text { (IM) }\end{array}$ & $\mathrm{CEF}$ & $2-8^{\circ} \mathrm{C}$ & 36 & $\begin{array}{l}\text { lyophilized: } \\
3 \text { months } \\
\left(37^{\circ} \mathrm{C}\right)\end{array}$ & $\begin{array}{l}\text { SPC, Barth } \\
\text { et al., } 1983\end{array}$ \\
\hline & Rabipur & $\begin{array}{l}\text { Novartis (Ger- } \\
\text { many) }\end{array}$ & $\begin{array}{l}\text { potassium-L- } \\
\text { glutamate, polyge- } \\
\text { line, sucrose }\end{array}$ & $\begin{array}{l}\text { lyophilized } \\
\text { (IM) }\end{array}$ & $\mathrm{CEF}$ & $2-8^{\circ} \mathrm{C}$ & 48 & $\mathrm{~N} / \mathrm{A}$ & SPC \\
\hline & Verorab & $\begin{array}{l}\text { Sanofi Pasteur } \\
\text { (France) }\end{array}$ & maltose, HSA & $\begin{array}{l}\text { lyophilized } \\
\text { (IM/ID) }\end{array}$ & Vero & $2-8^{\circ} \mathrm{C}$ & 36 & N/A & SPC \\
\hline \multirow[t]{2}{*}{ Yellow fever } & YF-Vax & $\begin{array}{l}\text { Sanofi Pasteur } \\
\text { (USA) }\end{array}$ & gelatin, sorbitol & $\begin{array}{l}\text { lyophilized } \\
\text { (SC) }\end{array}$ & $\mathrm{ALVFCE}^{27}$ & $\begin{array}{l}2-8^{\circ} \mathrm{C} \\
\text { (FrSen) }\end{array}$ & 12 & $\begin{array}{l}\text { lyophilized: } \\
14 \text { days } \\
\left(37^{\circ} \mathrm{C}\right) \\
4 \text { days } \\
\left(47^{\circ} \mathrm{C}\right) \text {; } \\
\text { reconsti- } \\
\text { tuted: } 1 \text { h } \\
\left(25^{\circ} \mathrm{C}\right)\end{array}$ & SPC \\
\hline & Stamaril & $\begin{array}{l}\text { Sanofi Pasteur } \\
\text { (France) }\end{array}$ & $\begin{array}{l}\text { lactose, sorbitol, } \\
\text { L-histidine HCL, } \\
\text { L-alanine }\end{array}$ & $\begin{array}{l}\text { lyophilized } \\
\text { (IM or SC) }\end{array}$ & ALVFCE & $\begin{array}{l}2-8^{\circ} \mathrm{C} \\
\text { (FrSen) }\end{array}$ & 36 & $\begin{array}{l}\text { reconsti- } \\
\text { tuted: } 6 \mathrm{~h} \\
\left(2-8^{\circ} \mathrm{C}\right)\end{array}$ & SPC \\
\hline \multicolumn{10}{|c|}{ SUBUNIT/ RECOMBINANT } \\
\hline \multirow[t]{2}{*}{ Hepatitis B } & Engerix B & GSK (Belgium) & $\begin{array}{l}\mathrm{Al}(\mathrm{OH})_{3} \\
\text { (adjuvant), } \\
\text { polysorbate } 20\end{array}$ & liquid (IM) & $\begin{array}{l}\text { yeast } \\
\left(\mathrm{HBsAg}^{28}\right)\end{array}$ & $\begin{array}{l}2-8^{\circ} \mathrm{C} \\
\text { (FrSen) }\end{array}$ & 36 & $\begin{array}{l}\text { lyophilized: } \\
72 \mathrm{~h}\left(25^{\circ} \mathrm{C}\right)\end{array}$ & SPC \\
\hline & $\begin{array}{l}\text { Recombivax } \\
\mathrm{HB}\end{array}$ & Merck (USA) & $\mathrm{Al}(\mathrm{OH})_{3}(\mathrm{Adj})$ & liquid (IM) & yeast & $\begin{array}{l}2-8^{\circ} \mathrm{C} \\
\text { (FrSen) }\end{array}$ & 36 & N/A & SPC \\
\hline \multirow[t]{2}{*}{ Influenza } & FluBlock & $\begin{array}{l}\text { Protein Sciences } \\
\text { (USA) }\end{array}$ & Polysorbate 20 & liquid (IM) & $\begin{array}{l}\text { SF9 }^{28} \\
\text { HA- } \\
\text { VLPs }^{30}\end{array}$ & $\begin{array}{l}2-8^{\circ} \mathrm{C} \\
\text { (FrSen) }\end{array}$ & 4 & N/A & SPC \\
\hline & $\begin{array}{l}\text { Celtura } \\
(\mathrm{H} 1 \mathrm{~N} 1)\end{array}$ & $\begin{array}{l}\text { Novartis (Ger- } \\
\text { many) }\end{array}$ & MF59 (adjuvant) & liquid (IM) & MDCK & $\begin{array}{l}2-8^{\circ} \mathrm{C} \\
\text { (FrSen) }\end{array}$ & 6 & N/A & SPC \\
\hline \multirow[t]{2}{*}{$\begin{array}{l}\text { Human Pap- } \\
\text { illoma Virus } \\
(\mathrm{Pr})\end{array}$} & Cervarix & GSK (Belgium) & AS04 ${ }^{31}$ (adjuvant) & liquid (IM) & $\begin{array}{l}\text { BTI- } \\
\text { TN5B1- } \\
4^{32}, \text { L1- } \\
\text { VLPs }\end{array}$ & $\begin{array}{l}2-8^{\circ} \mathrm{C} \\
\text { (FrSen) }\end{array}$ & 48 & $\begin{array}{l}1 \text { month } \\
\left(25^{\circ} \mathrm{C}\right), 7 \\
\text { days }\left(37^{\circ} \mathrm{C}\right)\end{array}$ & $\begin{array}{l}\text { SPC, Le } \\
\text { Tallec et } \\
\text { al., } 2009\end{array}$ \\
\hline & Gardasil & Merck (USA) & $\begin{array}{l}\text { aluminium hy- } \\
\text { droxyphosphate } \\
\text { (adjuvant), L- } \\
\text { histidine, polys- } \\
\text { orbate } 80\end{array}$ & liquid (IM) & $\begin{array}{l}\text { yeast } \\
\text { VLPs }\end{array}$ & $\begin{array}{l}2-8^{\circ} \mathrm{C} \\
\text { (FrSen) }\end{array}$ & 36 & $\begin{array}{l}130 \text { months } \\
\left(25^{\circ} \mathrm{C}\right), 18 \\
\text { months } \\
\left(37^{\circ} \mathrm{C}\right), 3 \\
\text { months } \\
\left(42^{\circ} \mathrm{C}\right)\end{array}$ & $\begin{array}{l}\text { SPC, } \\
\text { Shank- } \\
\text { Retzlaff et } \\
\text { al., } 2006\end{array}$ \\
\hline \multicolumn{10}{|c|}{ COMBINATORY } \\
\hline $\begin{array}{l}\text { DT/Poliovi- } \\
\text { rus/Hepati- } \\
\text { tis B }\end{array}$ & Pediarix & GSK (Belgium) & $\begin{array}{l}\text { aluminium salts } \\
\text { (adjuvant) }\end{array}$ & liquid (IM) & yeast/Vero & $\begin{array}{l}2-8^{\circ} \mathrm{C} \\
\text { (FrSen) }\end{array}$ & N/A & $\begin{array}{l}72 \mathrm{~h} \\
\left(8-25^{\circ} \mathrm{C}\right)\end{array}$ & SPC \\
\hline
\end{tabular}




\begin{tabular}{|c|c|c|c|c|c|c|c|c|c|}
\hline & $\begin{array}{l}\text { Product } \\
\text { name }\end{array}$ & Company & Stabilizers & Pres/adm ${ }^{1}$ & FPPS $^{2}$ & Storage & $\begin{array}{l}\text { Shelf-life } \\
\text { (months) }\end{array}$ & $\begin{array}{l}\text { Thermosta- } \\
\text { bility }\end{array}$ & Ref \\
\hline $\begin{array}{l}\text { DTP/inacti- } \\
\text { vated Polio }\end{array}$ & Kinrix & GSK (Belgium) & $\begin{array}{l}\mathrm{Al}(\mathrm{OH})_{3} \\
\text { (adjuvant) }\end{array}$ & liquid (IM) & mVero & $\begin{array}{l}2-8^{\circ} \mathrm{C} \\
\text { (FrSen) }\end{array}$ & 36 & $\mathrm{~N} / \mathrm{A}$ & SPC \\
\hline $\begin{array}{l}\text { Hepatitis } \\
A \text { and } B\end{array}$ & Twinrix & GSK (Belgium) & $\begin{array}{l}\text { aluminium phos- } \\
\text { phate/hydroxide } \\
\text { (adjuvant), amino } \\
\text { acids, polysorb- } \\
\text { ate } 20\end{array}$ & liquid (IM) & $\begin{array}{l}\text { MRC-5/ } \\
\text { yeasts }\end{array}$ & $\begin{array}{l}2-8^{\circ} \mathrm{C} \\
\text { (FrSen) }\end{array}$ & 36 & $\begin{array}{l}2 \text { weeks } \\
\left(21^{\circ} \mathrm{C}\right), 1 \\
\text { week }\left(37^{\circ} \mathrm{C}\right)\end{array}$ & $\begin{array}{l}\text { SPC Caus- } \\
\text { er, } 2005\end{array}$ \\
\hline \multirow[t]{4}{*}{$\begin{array}{l}\text { Measles, } \\
\text { Mumps and } \\
\text { Rubella }\end{array}$} & MMR II & Merck (USA) & $\begin{array}{l}\text { hydrolyzed gela- } \\
\text { tin, recombinant } \\
\text { HSA, sorbitol, } \\
\text { sucrose }\end{array}$ & $\begin{array}{l}\text { lyophilized } \\
\text { (SC) }\end{array}$ & $\begin{array}{l}\text { CEF/ WI- } \\
38\end{array}$ & frozen & 24 & $\begin{array}{l}\text { lyophilized: } \\
7 \text { days } \\
\left(37^{\circ} \mathrm{C}\right) \\
\text { reconsti- } \\
\text { tuted: } 8 \text { h } \\
\left(2-5^{\circ} \mathrm{C}\right)\end{array}$ & SPC \\
\hline & $\begin{array}{l}\text { Trimovax } \\
\text { Merieux }\end{array}$ & $\begin{array}{l}\text { Sanofi Pasteur } \\
\text { (France) }\end{array}$ & HSA & $\begin{array}{l}\text { lyophilized } \\
\text { (SC/IM) }\end{array}$ & $\begin{array}{l}\mathrm{CEF} / \\
\mathrm{SPFCE} / \\
\text { WI-38 }\end{array}$ & $2-8^{\circ} \mathrm{C}$ & 24 & $\mathrm{~N} / \mathrm{A}$ & SPC \\
\hline & Tresivac & SII (India) & none reported & $\begin{array}{l}\text { lyophilized } \\
\text { (SC) }\end{array}$ & $\begin{array}{l}\mathrm{HDC/} \\
\mathrm{CEF}\end{array}$ & $2-8^{\circ} \mathrm{C}$ & 24 & N/A & SPC \\
\hline & Abhayvac 3 & $\begin{array}{l}\text { Indian Immu- } \\
\text { nologicals Ltd. } \\
\text { (India) }\end{array}$ & $\begin{array}{l}\text { sorbitol, gelatin, } \\
\text { L-arginin, L- } \\
\text { alanin, maltose, } \\
\text { LAH }\end{array}$ & $\begin{array}{l}\text { lyophilized } \\
\text { (SC) }\end{array}$ & $\begin{array}{l}\mathrm{HDC} / \\
\mathrm{CEF}\end{array}$ & $2-8^{\circ} \mathrm{C}$ & 24 & N/A & SPC \\
\hline \multirow{2}{*}{$\begin{array}{l}\text { Measles, } \\
\text { Mumps, } \\
\text { Rubella and } \\
\text { Varicella }\end{array}$} & Priorix Tetra & GSK (Belgium) & $\begin{array}{l}\text { lactose, amino } \\
\text { acids, sorbitol, } \\
\text { mannitol }\end{array}$ & $\begin{array}{l}\text { lyophilized } \\
\text { (SC) }\end{array}$ & $\begin{array}{l}\text { CEF/ WI- } \\
38\end{array}$ & $2-8^{\circ} \mathrm{C}$ & 18 & N/A & SPC \\
\hline & ProQuad & Merck (USA) & $\begin{array}{l}\text { sucrose, sorbitol, } \\
\text { hydrolyzed gela- } \\
\text { tin, monosodium } \\
\text { L-glutamate, HSA }\end{array}$ & $\begin{array}{l}\text { lyophilized } \\
\text { (SC) }\end{array}$ & $\begin{array}{l}\text { CEF/ } \\
\text { WI-38/ } \\
\text { MRC-5 }\end{array}$ & frozen & 18 & $\begin{array}{l}\text { lyophilized: } \\
72 \mathrm{~h}\left(2-8^{\circ} \mathrm{C}\right)\end{array}$ & SPC \\
\hline
\end{tabular}

${ }^{1}$ Pres $(\mathrm{Adm})=$ presentation (administration route); ${ }^{2} \mathrm{FPPS}=$ final propagation or production substrate; ${ }^{3} \mathrm{Ref}=$ references; ${ }^{4} \mathrm{HSA}=$ human serum albumin; ${ }^{5} \mathrm{WI}-38$ = human diploid cell line from lung tissue; ${ }^{6} \mathrm{FrSen}=$ freeze sensitive; ${ }^{7} \mathrm{~N} / \mathrm{A}=$ data not available; ${ }^{8} \mathrm{SPC}=$ supplementary product characteristics; ${ }^{9} \mathrm{SPFCE}=$ specific pathogen free chicken eggs ${ }^{10} \mathrm{SII}=$ Serum Institute of India; ${ }^{11} \mathrm{LAH}=$ lactalbumin hydrolysate; ${ }^{12} \mathrm{SC}=$ subcutaneous; ${ }^{13} \mathrm{CEF}=$ chicken embryonic cells; ${ }^{14} \mathrm{IM}=$ intramuscular; ${ }^{15} \mathrm{HDC}=$ human diploid cells; ${ }^{16} \mathrm{GPO}=$ Government Pharmaceutical Organization; ${ }^{17} \mathrm{MRC}-5=$ normal human fetal lung fibroblast; ${ }^{18} \mathrm{TOPV}=$ trivalent oral polio vaccine; ${ }^{19} \mathrm{GSK}=$ Glaxo SmithKline; ${ }^{20} \mathrm{FBS}=$ fetal bovine serum; ${ }^{21} \mathrm{PC}=$ percutaneous route $(\mathrm{scarifica}-$ tion); ${ }^{22}$ susMDCK = Madin Darby canine kidney cells grown in suspension; ${ }^{23} \mathrm{ASO} 3=$ composed of squalene, DL- $\alpha$-tocopherol and polysorbate; ${ }^{24} \mathrm{MF} 59$ = adjuvant composed of squalene; ${ }^{25} \mathrm{AF} 03$ = adjuvant composed of squalene, sorbitan oleate, polyoxyethylene cetostearyl ether, mannitol; ${ }^{26} \mathrm{mVero}=$ Vero cells grown in microcarriers; ${ }^{27} \mathrm{ALVFCE}=$ avian sarcoma leukosis virus free chicken embryos; ${ }^{28} \mathrm{HBs} \mathrm{Ag}=$ hepatitis B virus surface antigen; ${ }^{29} \mathrm{SF} 9=\mathrm{clonal}$ isolate of Spodoptera frugiperda Sf21 insect cells; ${ }^{30} \mathrm{VLPs}=$ viral-like particles; ${ }^{31} \mathrm{ASO} 4=$ adjuvant composed of monophosphoryl lipid A adsorbed on to aluminum hydroxide salt; ${ }^{32} \mathrm{BTI}-\mathrm{TN} 5 \mathrm{~B} 1-4$ = insect cell line from Trichoplusia ni.

Supplementary Table S4. Representative experimental viral vaccines

\begin{tabular}{|c|c|c|c|c|c|c|c|}
\hline & Product name & Company & Pres/adm ${ }^{1}$ & Stabilizers & Adjuvant & Thermostability & Ref \\
\hline \multicolumn{8}{|c|}{ INACTIVATED } \\
\hline \multirow[t]{4}{*}{ Influenza } & $\begin{array}{l}\text { Nanopatch (micro- } \\
\text { needles/ } \\
\text { Fluvax) }\end{array}$ & $\begin{array}{l}\text { University of } \\
\text { Queensland/ } \\
\text { CLS limited } \\
\text { (Australia) }\end{array}$ & $\begin{array}{l}\text { coated micro- } \\
\text { needles }\left(\mathrm{ID}^{2}\right)\end{array}$ & trehalose & no & $\begin{array}{l}6 \text { months }\left(23^{\circ} \mathrm{C}\right) \text {, } \\
8 \mathrm{~h}\left(37^{\circ} \mathrm{C}\right)\end{array}$ & $\begin{array}{l}\text { Chen X et al., } \\
2011\end{array}$ \\
\hline & $\begin{array}{l}\text { Inactivated influenza } \\
\text { nano emulsion }\end{array}$ & $\begin{array}{l}\text { Nanobio/Merck } \\
\text { (USA) }\end{array}$ & liquid $\left(\mathrm{IN}^{3}\right)$ & $\mathrm{W}_{80} 5 \mathrm{EC}^{4}$ & $\begin{array}{l}\text { nanoemul- } \\
\text { sion }\end{array}$ & $\begin{array}{l}1 \text { months }\left(2-8^{\circ} \mathrm{C}\right) \text {, } \\
1 \text { months }\left(25^{\circ} \mathrm{C}\right)\end{array}$ & $\begin{array}{l}\text { Hamouda et } \\
\text { al., } 2010\end{array}$ \\
\hline & Influenza virosomes & $\begin{array}{l}\text { University of } \\
\text { Groningen } \\
\text { (The Nether- } \\
\text { lands) }\end{array}$ & $\begin{array}{l}\text { lyophilized } \\
\text { (injected) }\end{array}$ & inulin & virosomes & $\begin{array}{l}12 \text { weeks }\left(20^{\circ} \mathrm{C}\right), 3 \\
\text { weeks }\left(42^{\circ} \mathrm{C}\right)\end{array}$ & $\begin{array}{l}\text { de Jonge et al., } \\
2007\end{array}$ \\
\hline & Influenza virosomes & $\begin{array}{l}\text { Pevion } \\
\text { (Switzerland) }\end{array}$ & lyophilized & $\begin{array}{l}\text { sucrose, }(\mathrm{DC}- \\
\text { chol, TC-chol, } \\
\text { DOTAPDHAB) }\end{array}$ & virosomes & $\begin{array}{l}>12 \text { months } \\
\left(25^{\circ} \mathrm{C}\right), \mathrm{F} / \mathrm{T}^{6} \mathrm{re}- \\
\text { sistant }\end{array}$ & $\begin{array}{l}\text { Kammer et al., } \\
2007\end{array}$ \\
\hline
\end{tabular}




\begin{tabular}{|c|c|c|c|c|c|c|c|}
\hline & Product name & Company & Pres/adm ${ }^{1}$ & Stabilizers & Adjuvant & Thermostability & Ref \\
\hline & $\begin{array}{l}\text { Dry powder influenza } \\
\text { vaccine }\end{array}$ & $\begin{array}{l}\text { University of } \\
\text { N. Carolina } \\
\text { at Chapel Hill } \\
\text { (USA) }\end{array}$ & $\mathrm{SFD}^{7}(\mathrm{IN})$ & trehalose & no & $\begin{array}{l}>12 \text { weeks }\left(25^{\circ} \mathrm{C}\right), \\
2 \text { weeks }\left(37^{\circ} \mathrm{C}\right)\end{array}$ & $\begin{array}{l}\text { Garmise et al., } \\
2007\end{array}$ \\
\hline & $\begin{array}{l}\text { Dry powder influenza } \\
\text { vaccine }\end{array}$ & $\begin{array}{l}\text { PowderJect } \\
\text { (USA) }\end{array}$ & $\mathrm{SFD}^{7}(\mathrm{ID})$ & $\begin{array}{l}\text { trehalose, man- } \\
\text { nitol, dextran }\end{array}$ & no & $>3$ months $\left(40^{\circ} \mathrm{C}\right)$ & $\begin{array}{l}\text { Maa et al., } \\
2004\end{array}$ \\
\hline & $\begin{array}{l}\text { Inactivated influenza } \\
\text { vaccine }\end{array}$ & Stabilitech (UK) & lyophilized (SC) & N/A & no & $>6$ months $\left(45^{\circ} \mathrm{C}\right)$ & $\begin{array}{l}\text { Stabilitech, } \\
2011\end{array}$ \\
\hline & Thermostable IM flu & $\begin{array}{l}\text { Variation } \\
\text { Biotechnologies } \\
\text { (USA) }\end{array}$ & $\begin{array}{l}\text { lyophilized } \\
\text { (injected) }\end{array}$ & N/A & $\mathrm{LPV}^{8}$ & 6 months $\left(40^{\circ} \mathrm{C}\right)$ & $\begin{array}{l}\text { VBI vaccines, } \\
2016\end{array}$ \\
\hline \multirow[t]{2}{*}{ Pandemic } & $\begin{array}{l}\text { Whole inactivated } \\
\text { H5N1 }\end{array}$ & $\begin{array}{l}\text { University of } \\
\text { Groningen (The } \\
\text { Netherlands) }\end{array}$ & $\begin{array}{l}\text { lyophilized } \\
\text { (Injected) }\end{array}$ & inulin & no & $\begin{array}{l}>1 \text { year }\left(25^{\circ} \mathrm{C}\right) ; 3 \\
\text { months }\left(40^{\circ} \mathrm{C}\right)\end{array}$ & $\begin{array}{l}\text { Geeraedts et } \\
\text { al., } 2010\end{array}$ \\
\hline & $\mathrm{H} 5 \mathrm{~N} 1$ & $\begin{array}{l}\text { Apogee Tech- } \\
\text { nology (USA) }\end{array}$ & injected & $\mathrm{PCPP}^{8}$ & РCPP & $30 \mathrm{~h}\left(40^{\circ} \mathrm{C}\right)$ & $\begin{array}{l}\text { Andrianov et } \\
\text { al., } 2011\end{array}$ \\
\hline \multicolumn{8}{|l|}{ VIRUS VECTORS } \\
\hline Adenovirus & Adenovirus & Stabilitech(UK) & liq / lyo & N/A & N/A & $\begin{array}{l}\text { liquid } 6 \text { months } \\
\left(2-8^{\circ} \mathrm{C}\right) \text {, lyo. } 3 \\
\text { months }\left(37^{\circ} \mathrm{C}\right)\end{array}$ & $\begin{array}{l}\text { Stabilitech, } \\
2012\end{array}$ \\
\hline \multirow[t]{2}{*}{ Influenza } & $\begin{array}{l}\text { ND1.1 (Adenovirus } \\
\text { vector-HA-dsRNA) } \\
\text { (H5) }\end{array}$ & Vaxart (USA) & $\begin{array}{l}\text { dried capsules } \\
\text { (oral) }\end{array}$ & not known & $\begin{array}{l}\text { dsRNA } \\
\text { (TLR3 an- } \\
\text { tagonist) }\end{array}$ & $\begin{array}{l}1 \text { month }\left(25^{\circ} \mathrm{C}\right), 3 \\
\text { months }\left(40^{\circ} \mathrm{C}\right)\end{array}$ & $\begin{array}{l}\text { Vaxart } \\
, 2016\end{array}$ \\
\hline & $\begin{array}{l}\text { Recombinant Modified } \\
\text { Vaccinia Ankara }\end{array}$ & $\begin{array}{l}\text { Erasmus Uni- } \\
\text { versity (The } \\
\text { Netherlands) }\end{array}$ & injected & not known & no & 4 weeks $\left(37^{\circ} \mathrm{C}\right)$ & $\begin{array}{l}\text { Rimmelzwaan } \\
\text { and Suttter, } \\
2009\end{array}$ \\
\hline $\begin{array}{l}\text { Japanese en- } \\
\text { cephalitis }\end{array}$ & $\begin{array}{l}\text { Vero cells derived JE } \\
\text { vaccine }\end{array}$ & $\begin{array}{l}\text { Kitasato Insti- } \\
\text { tute (Japan) }\end{array}$ & liquid (injected) & glycine, sorbitol & no & $\begin{array}{l}12 \text { months } \\
\left(2-8^{\circ} \mathrm{C}\right), 12 \\
\text { months }\left(28^{\circ} \mathrm{C}\right)\end{array}$ & $\begin{array}{l}\text { Toriniwa and } \\
\text { Komiya, } 2008\end{array}$ \\
\hline Yellow fever (En) & $\begin{array}{l}\text { XRX-001 (inactivated } \\
\text { YF vacine) }\end{array}$ & Xcellerex (USA) & liquid (injected) & $\begin{array}{l}\text { proprietary } \\
\text { stabilizers }\end{array}$ & $\mathrm{Al}(\mathrm{OH})_{3}$ & $\begin{array}{l}6 \text { months }\left(2-8^{\circ} \mathrm{C}\right) \text {, } \\
8 \text { weeks }\left(25^{\circ} \mathrm{C}\right)\end{array}$ & $\begin{array}{l}\text { Monath et al., } \\
2010\end{array}$ \\
\hline \multicolumn{8}{|c|}{ LIVE ATTENUATED } \\
\hline \multirow[t]{2}{*}{ Dengue } & $\begin{array}{l}\text { ChimeriVax Tetrava- } \\
\text { lent }\end{array}$ & $\begin{array}{l}\text { Sanofi Pasteur } \\
\text { (France) }\end{array}$ & $\begin{array}{l}\text { lyophilized } \\
\text { (injected) }\end{array}$ & $\mathrm{N} / \mathrm{A}$ & no & $\begin{array}{l}1 \text { month }\left(25^{\circ} \mathrm{C}\right), 7 \\
\text { days }\left(37^{\circ} \mathrm{C}\right)\end{array}$ & $\begin{array}{l}\text { Guy et al., } \\
2011\end{array}$ \\
\hline & DenVax & $\begin{array}{l}\text { CDC, Inviragen/ } \\
\text { Takeda (USA/ } \\
\text { Japan) }\end{array}$ & $\begin{array}{l}\text { lyophilized } \\
\text { (SC/ID) }\end{array}$ & $\begin{array}{l}\text { trehalose, rec } \\
\text { HSA, F127 }\end{array}$ & no & $\begin{array}{l}\text { freeze/thaw, re- } \\
\text { sistant, } 11 \text { weeks } \\
\left(2-8^{\circ} \mathrm{C}\right), 7 \text { days } \\
\left(25^{\circ} \mathrm{C}\right) \\
8 \mathrm{~h}\left(37^{\circ} \mathrm{C}\right)\end{array}$ & $\begin{array}{l}\text { Wiggan et al., } \\
2011\end{array}$ \\
\hline Yellow fever & YF vaccine & $\begin{array}{l}\text { Biomanguinhos } \\
\text { (Brazil) }\end{array}$ & liquid (injected) & $\begin{array}{l}\text { hydrolysed } \\
\text { gelatin, sucrose, } \\
\text { amino acids }\end{array}$ & no & 2 weeks $\left(37^{\circ} \mathrm{C}\right)$ & $\begin{array}{l}\text { Freire et al., } \\
2005\end{array}$ \\
\hline \multirow[t]{5}{*}{ Measles } & $\begin{array}{l}\text { Measles vaccine dry } \\
\text { powder (MVDP) }\end{array}$ & $\begin{array}{l}\text { University of } \\
\text { Colorado, SII } \\
\text { (USA/India) }\end{array}$ & $\begin{array}{l}\text { dry powder } \\
(\mathrm{CAN}-\mathrm{BD})^{9}\end{array}$ & $\begin{array}{l}\text { myo-inositol, } \\
\text { +/- sorbitol or } \\
\text { mannitol }\end{array}$ & no & $\begin{array}{l}6 \text { months }\left(25^{\circ} \mathrm{C}\right) \text {, } \\
1 \text { week }\left(37^{\circ} \mathrm{C}\right)\end{array}$ & Rota, 2011 \\
\hline & Measles vaccine & $\begin{array}{l}\text { Aridis Pharma- } \\
\text { ceuticals, SII } \\
\text { (USA/India) }\end{array}$ & $\begin{array}{l}\text { spray dried } \\
\text { (pulmonary, } \\
\text { injected) }\end{array}$ & $\begin{array}{l}\text { trehalose, su- } \\
\text { crose, divalent } \\
\text { cations, } \\
\text { L-arginine }\end{array}$ & no & 8 weeks $\left(37^{\circ} \mathrm{C}\right)$ & $\begin{array}{l}\text { Burger et al., } \\
2008\end{array}$ \\
\hline & Measles vaccine & Stabilitech (UK) & lyophilized (SC) & N/A & no & $\begin{array}{l}\text { resistant to } 5 \\
\text { freeze/thaw cycles; } \\
4 \mathrm{~h}\left(37^{\circ} \mathrm{C}\right), 6 \text { days } \\
\left(37^{\circ} \mathrm{C}\right)\end{array}$ & $\begin{array}{l}\text { Stabilitech, } \\
2012\end{array}$ \\
\hline & Measles vaccine & $\begin{array}{l}\text { TransForm } \\
\text { Pharmaceuti- } \\
\text { cals/SII (USA/ } \\
\text { India) }\end{array}$ & liquid & $\begin{array}{l}\text { porcine gelatin, } \\
\text { sucrose, treha- } \\
\text { lose, glycine, } \\
\text { serine, tricine }\end{array}$ & no & $\begin{array}{l}<1 \log \text { loss } 8 \mathrm{~h} \\
\left(40^{\circ} \mathrm{C}\right)\end{array}$ & $\begin{array}{l}\text { Schlehuber et } \\
\text { al., } 2011\end{array}$ \\
\hline & Measles Vaccine & $\begin{array}{l}\text { Aridis Pharma- } \\
\text { ceuticals (USA) }\end{array}$ & spray dried & $\begin{array}{l}\text { gelatin, HA, } \\
\text { glycerol, treha- } \\
\text { lose, sucrose, } \\
\text { L-arginine }\end{array}$ & no & $\begin{array}{l}>0.7 \log \text { loss at } 2 \\
\text { weeks }\left(37^{\circ} \mathrm{C}\right)\end{array}$ & $\begin{array}{l}\text { Ohtake et al., } \\
2009\end{array}$ \\
\hline
\end{tabular}




\begin{tabular}{|c|c|c|c|c|c|c|c|}
\hline & Product name & Company & Pres/adm ${ }^{1}$ & Stabilizers & Adjuvant & Thermostability & Ref \\
\hline & Measles Vaccine & $\begin{array}{l}\text { University of } \\
\text { Kansas (USA) }\end{array}$ & liquid & $\begin{array}{l}\text { porcine gela- } \\
\text { tin, mannitol, } \\
\text { myo-inositol, } \\
\text { proline, malic } \\
\text { acid }\end{array}$ & no & $\begin{array}{l}\text { retention of } 50 \% \\
-70 \% \text { of infectiv- } \\
\text { ity for } 24 \text { hours } \\
\left(21^{\circ} \mathrm{C}\right)\end{array}$ & $\begin{array}{l}\text { Kissman et al., } \\
2008\end{array}$ \\
\hline & Measles Vaccine & $\begin{array}{l}\text { Univer- } \\
\text { sity of Colorado } \\
\text { (USA)/ SII }\end{array}$ & spray dried & $\begin{array}{l}\text { gelatin, LAH, } \\
\text { myo-inositol, } \\
\text { mannitol, } \\
\text { L-arginine, L- } \\
\text { alanine, L-histi- } \\
\text { dine, tricine }\end{array}$ & no & $\begin{array}{l}0.6 \log \\
\text { loss in } 7 \text { days } \\
\left(37^{\circ} \mathrm{C}\right)\end{array}$ & $\begin{array}{l}\text { Burger et al., } \\
2008\end{array}$ \\
\hline Mumps & Mumps vaccine & $\begin{array}{l}\text { Serum Research } \\
\text { Institute (Iran) }\end{array}$ & lyophilized (SC) & $\begin{array}{l}\text { hydrolyzed } \\
\text { gelatin, treha- } \\
\text { lose, sodium } \\
\text { glutamate }\end{array}$ & no & $\begin{array}{l}\text { reconstituted } \\
\text { (predicted): } 155 \mathrm{~h} \\
\left(4^{\circ} \mathrm{C}\right) \\
79 \mathrm{~h}\left(25^{\circ} \mathrm{C}\right), \\
21 \mathrm{~h}\left(37^{\circ} \mathrm{C}\right)\end{array}$ & $\begin{array}{l}\text { Jamil et al., } \\
2014\end{array}$ \\
\hline Polio & Trivalent OPV & $\begin{array}{l}\text { Sapporo Medi- } \\
\text { cal University } \\
\text { (Japan) }\end{array}$ & liquid (oral) & sorbitol & no & 7 days $\left(37^{\circ} \mathrm{C}\right)$ & $\begin{array}{l}\text { Shiomi et al., } \\
2003\end{array}$ \\
\hline & Trivalent OPV & $\begin{array}{l}\text { Institute Pasteur } \\
\text { (France) }\end{array}$ & liquid (oral) & $\mathrm{MgCl} 2+\mathrm{D} 2 \mathrm{O}$ & no & $\begin{array}{l}\text { 3-7 days }\left(37^{\circ} \mathrm{C}\right), 3 \\
\text { days }\left(45^{\circ} \mathrm{C}\right)\end{array}$ & $\begin{array}{l}\text { Crainic et al., } \\
1996\end{array}$ \\
\hline Rotavirus & Rotavirus vaccine & $\begin{array}{l}\text { Aridis Pharma- } \\
\text { ceuticals, Johns } \\
\text { Hopkins (USA) }\end{array}$ & thin film (oral) & $\mathrm{N} / \mathrm{A}$ & no & $\mathrm{N} / \mathrm{A}$ & $\begin{array}{l}\text { Johns Hop- } \\
\text { skins Univer- } \\
\text { sity, } 2007\end{array}$ \\
\hline \multicolumn{8}{|c|}{ SUBUNIT/RECOMBINANT } \\
\hline \multirow[t]{2}{*}{ Influenza } & $\begin{array}{l}\text { dry powder Influenza } \\
\text { vaccine }\end{array}$ & $\begin{array}{l}\text { University of } \\
\text { Groningen (The } \\
\text { Netherlands) }\end{array}$ & $\begin{array}{l}\text { lyophilized (in- } \\
\text { jected) }\end{array}$ & $\begin{array}{l}\text { trehalose, } \\
\text { inulin }\end{array}$ & no & $\begin{array}{l}\text { inulin: } 6 \text { months } \\
\left(25^{\circ} \mathrm{C}\right) \text {, Trehalose: } \\
6 \text { months }\left(45^{\circ} \mathrm{C}\right)\end{array}$ & $\begin{array}{l}\text { Amorij et al., } \\
2007\end{array}$ \\
\hline & $\begin{array}{l}\text { Dry powder Influenza } \\
\text { vaccine }\end{array}$ & $\begin{array}{l}\text { University of } \\
\text { Groningen (The } \\
\text { Netherlands) }\end{array}$ & pulmonary & inulin & no & 3 years $\left(20^{\circ} \mathrm{C}\right)$ & $\begin{array}{l}\text { Saluja et al., } \\
2010\end{array}$ \\
\hline \multirow[t]{4}{*}{ Hepatitis B } & Shanvac-B & $\begin{array}{l}\text { Shantha Bio- } \\
\text { technics, PATH } \\
\text { (India) }\end{array}$ & spray dried (IM) & $\begin{array}{l}\text { trehalose, } \\
\text { mannitol }\end{array}$ & $\mathrm{Al}(\mathrm{OH})_{3}$ & 2 years $\left(37^{\circ} \mathrm{C}\right)$ & $\begin{array}{l}\text { Chen D et al., } \\
2010\end{array}$ \\
\hline & Shanvac-B & $\begin{array}{l}\text { Shantha Bio- } \\
\text { technics, PATH } \\
\text { (India) }\end{array}$ & liquid (IM) & $\begin{array}{l}\text { phosphate, } \\
\text { histidine }\end{array}$ & $\mathrm{Al}(\mathrm{OH})_{3}$ & $\begin{array}{l}6 \text { months }\left(37^{\circ} \mathrm{C}\right) \text {, } \\
6 \text { months }\left(45^{\circ} \mathrm{C}\right) \text {, } \\
9 \text { weeks }\left(55^{\circ} \mathrm{C}\right)\end{array}$ & $\begin{array}{l}\text { Jezek et al., } \\
2009\end{array}$ \\
\hline & Shanvac-B & $\begin{array}{l}\text { Shantha Bio- } \\
\text { technics, PATH } \\
\text { (India) }\end{array}$ & liquid (IM) & $\begin{array}{l}\text { phosphate, } \\
\text { histidine, pro- } \\
\text { pylene glycol }\end{array}$ & $\mathrm{Al}(\mathrm{OH})_{3}$ & $\begin{array}{l}\text { freeze/thaw resist- } \\
\text { ant, } \\
12 \text { months }\left(37^{\circ} \mathrm{C}\right)\end{array}$ & $\begin{array}{l}\text { Braun et al., } \\
2009 \mathrm{~b}\end{array}$ \\
\hline & HBsAg-NE & $\begin{array}{l}\text { University of } \\
\text { Michigan, Na- } \\
\text { nobio (USA) }\end{array}$ & liquid (IN) & $\mathrm{W}_{80} 5 \mathrm{EC}$ & $\begin{array}{l}\text { nanoemul- } \\
\text { sion }\end{array}$ & $\begin{array}{l}12 \text { years }\left(2-8^{\circ} \mathrm{C}\right) \text {, } \\
6 \text { months }(20- \\
\left.25^{\circ} \mathrm{C}\right), 6 \text { weeks } \\
\left(40^{\circ} \mathrm{C}\right)\end{array}$ & $\begin{array}{l}\text { Makidon et } \\
\text { al., } 2008\end{array}$ \\
\hline \multirow[t]{2}{*}{ Influenza } & $\begin{array}{l}\text { pfMBP-HA fusion } \\
\text { protein }\end{array}$ & $\begin{array}{l}\text { Nature Technol- } \\
\text { ogy Corporation } \\
\text { (USA) }\end{array}$ & $\begin{array}{l}\text { liquid (ID in } \\
\text { mice) }\end{array}$ & N/A & $\begin{array}{l}\text { recombinant } \\
\text { flagelin }\end{array}$ & 40 months $\left(75^{\circ} \mathrm{C}\right)$ & $\begin{array}{l}\text { Luke et al., } \\
2011\end{array}$ \\
\hline & $\begin{array}{l}\text { Microneedles coated } \\
\text { with influenza virus }\end{array}$ & $\begin{array}{l}\text { Georgia Insti- } \\
\text { tute of Technol- } \\
\text { ogy (USA) }\end{array}$ & $\begin{array}{l}\text { coated micro- } \\
\text { needles (ID } \\
\text { mice) }\end{array}$ & trehalose & no & 1 day $\left(37^{\circ} \mathrm{C}\right)$ & $\begin{array}{l}\text { Kim et al., } \\
2010\end{array}$ \\
\hline Rotavirus & $\begin{array}{l}\text { Bacillus subtilis spores } \\
\text { expressing VP6 }\end{array}$ & $\begin{array}{l}\text { Tufts University } \\
\text { (USA) }\end{array}$ & $\begin{array}{l}\text { lyophilized (IN } \\
\text { or Oral) }\end{array}$ & none & $\begin{array}{l}\text { cholera } \\
\text { toxin }\end{array}$ & spore heat stable. & Lee et al., 2010 \\
\hline
\end{tabular}

${ }^{1}$ Pres $(\mathrm{Adm})=$ presentation $($ administration route $) ;{ }^{2} \mathrm{ID}=$ intra dermal; ${ }^{3} \mathrm{IN}=$ intra nasal; ${ }^{4} \mathrm{~W}_{80} 5 \mathrm{EC}=$ nanoscale emulsion $(<800 \mathrm{~nm})$, containing surfactants, refined soybean oil, ethanol; stabilizers: ${ }^{5} \mathrm{DC}-\mathrm{chol}=3$ - $\left[N_{-}\left(N_{-}, N_{-}\right.\right.$-dimethylaminoethane $)$-carbamoyl $]$cholesterol hydrochloride, TC-chol = cholesteryl $N$-(trimethylammonioethyl) carbamate chloride, DOTAP = propyl]- $N, N, N$-trimethylammonium chloride, DHAB = dimethyldihexadecylammonium bromide; ${ }^{6} \mathrm{~F} / \mathrm{T}=$ freeze-thaw cycle; ${ }^{7} \mathrm{SFD}=$ spray freeze dried; ${ }^{7} \mathrm{LPV}=$ lipid particle vaccine; ${ }^{8} \mathrm{PCPP}=$ poly $\left[\right.$ di $($ carboxylatophenoxy)phosphazene $] ;{ }^{9} \mathrm{CAN}$ $\mathrm{BD}=$ carbon dioxide-assisted nebulization with a bubble dryer. 